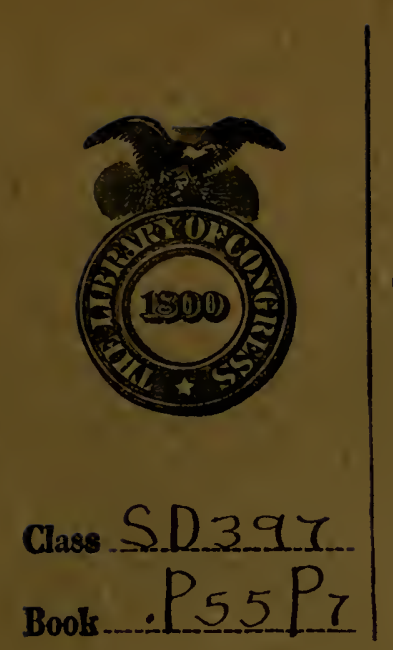

Title

Imprint

$$
\text { 19-80000-1 ipo }
$$



YaLe University

YALE FOREST SCHOOL-Bulletin'2

\title{
PROLONGING THE CUT OF SOUTHERN PINE
}

PART I. POSSIBILITIES ÓF A SECOND CUT

By Herman H. Chapman, Professor of Forest Management

PART II. CLOSE UTILIZATION OF TIMBER

By RalPh C. BRYANT, Professor of Lumbering

\author{
New Haven \\ Yale University Press \\ 1913 \\ Monegrapfi
}


PUBLICATIONS OF THE YALE FOREST SCHOOL

Catalogue.

A pamphlet giving a list of the faculty and students and describing the courses is published annually in November. This publication also briefly describes the equipment of the School, terms of admission, tuition fees, and other expenses. It is mailed free to any address on application.

\section{Bulletins and Memoirs.}

The Yale Forest School began in January, 1912, the publication of a series of Bulletins and Memoirs. They are published at irregular intervals and are distributed at a fixed price.

Bulletin I, Classification for Forestry Literature. Price 10 cents.

Bulletin II, Prolonging the Cut of Southern Pine. Price 25 cents.

\section{Miscellaneous Publications.}

Report of the Alumni Reunion, Yale Forest School. Price 50 cents. Outline for a Field Study of a Lumber Operation. Price 10 cents.

\section{In Preparation.}

History of the Yale Forest School, with Biographical Record of Classes (1901-1912).

Working Plan of the Forest Property of the New Haven Water Company.

Communications relating to publications should be addressed to the YALE FOREST SCHOOL, NEW HAVEN, CONN. Checks should be made out in favor of the Yale Forest School. Postage stamps will be accepted for amounts less than one dollar. 



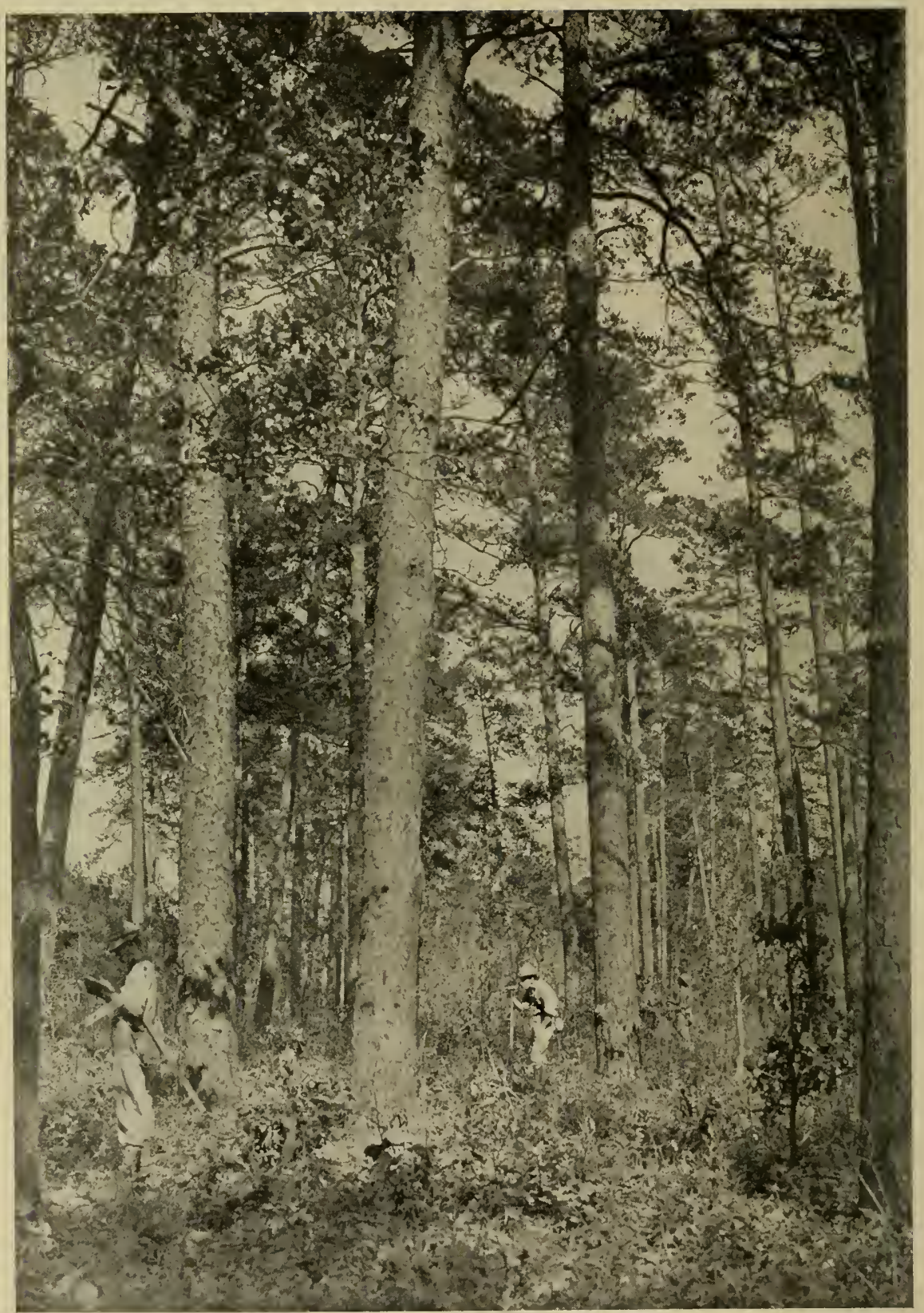

STUDENTS OF THE YALE FOREST SCHOOL CRUISING TIMBER IN A TEXAS SHORTLEAF PINE FOREST 


\section{Yalè Universiti}

YALE FOREST SCHOOL-Bulletin 2

\section{PROLONGING THE CUT OF SOUTHERN PINE}

PART 1. POSSIBILITIES OF A SECOND CUT

By Herman H. Chapman, Professor of Forest Management

PART II. CLOSE UTILIZATION OF TIMBER

By Ralph C. Bryant, Professor of Lumbering

New Haven

Yale University Press

1913 


\section{CONTENTS}

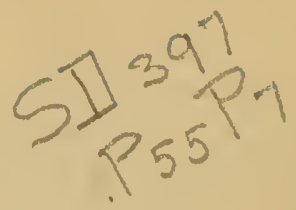

\section{Part I. Possibilities of a Second Cut}

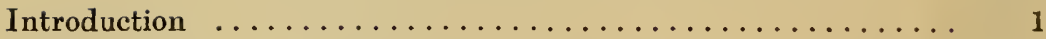

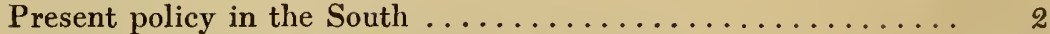

Report on lands in Ashley County, Arkansas ............ 3

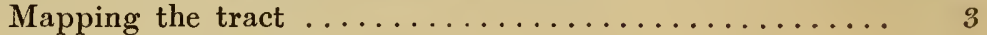

Estimate and description ................. 4

Composition of the forest $\ldots \ldots \ldots \ldots \ldots \ldots \ldots \ldots \ldots$

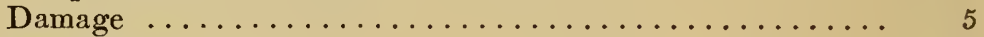

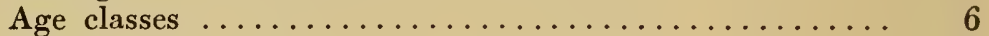

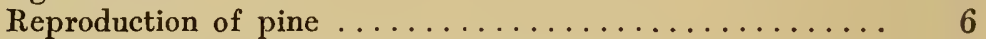

Growth of pine ........................ 7

Management of the tract $\ldots \ldots \ldots \ldots \ldots \ldots \ldots \ldots . \ldots \ldots$

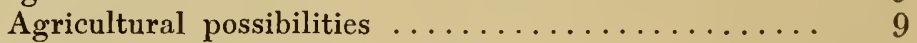

Securing a second cut of pine ............ 10

Condition of the cut-over lands ............ 10

Proposed plan for securing a better second cut ..... 11

Results of experimental marking for a second cut .... 11

Necessity of marking trees to be cut .......... 14

Growth in thinned stands ............... 14

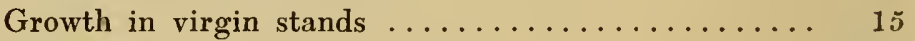

Increase in value of second cut ........... 16

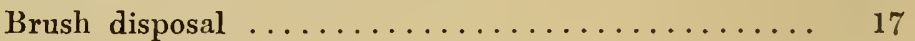

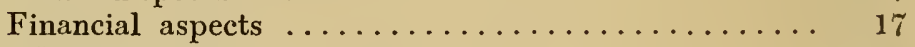

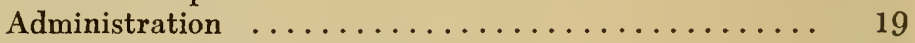

Sustained production of timber $\ldots \ldots \ldots \ldots \ldots \ldots \ldots . \ldots \ldots$

Summary of recommendations $\ldots \ldots \ldots \ldots \ldots \ldots \ldots .21$

\section{Part II. Close Utilization of Timber}

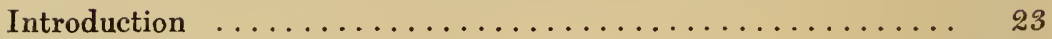

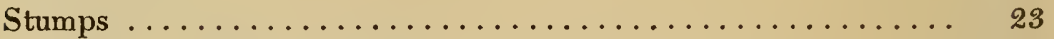

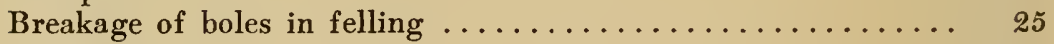

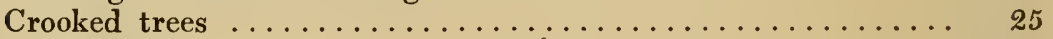

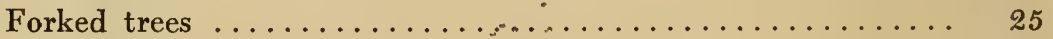

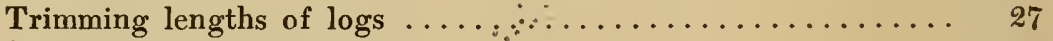

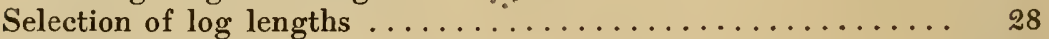

Waste in the top ............................ 29

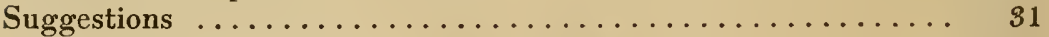

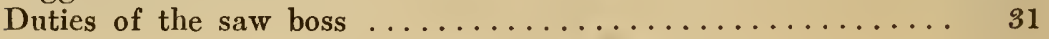




\section{ILLUSTRATIONS}

\section{Plates}

PAGE

Plate I. Students of the Yale Forest School cruising timber in a Texas shortleaf pine forest ......... Frontispiece

II. Fig. 1.-Top broken from falling on a stump ..... 33

Fig. 2.- Very crooked log ready for loading ..... 33

III. Fig. 1.-Example of very wasteful cutting of a

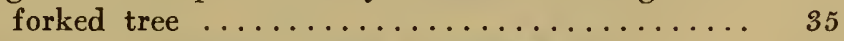

Fig. 2.-Unnecessary waste in log-making ...... 35

$1 \mathrm{~V}$. Fig. 1.-Section below the top shown in Plate V .. 37

Fig. 2.-Waste in a top .............. 37

V. Waste in the top of the tree shown in Plate IV, Fig. 139

\section{Text Figures}

Fig. 1, Method of cutting windfalls ............... 24

2. Forked tree improperly cut .............. 26

3. Forked trees improperly prepared ............ 27

4. Proper method of cutting rough tops .......... 29 


\section{TABLES}

PAGE

No. 1. Average growth in diameter breast high outside bark of shortleaf and loblolly pine in Ashley County, Arkansas

2. Average yield per acre of even-aged stands of shortleaf pine under ordinary conditions on large areas in Ashley County, Arkansas .................

3. Stand of timber on average forty acres of mature and old shortleaf and loblolly pine in Ashley County, Arkansas, showing total number of trees, those to be removed and those that would remain ..........

4. Stand of timber on average forty acres of mixed young and mature shortleaf and loblolly pine in Ashley County, Arkansas, showing total number of trees, those to be removed, and those that would remain ..

5. Amount of timber in stump sections of various diameters and lengths, showing the waste in high stumps ....

6. Measurements on cut-over lands in Ashley County, Arkansas, showing the lack of close utilization .... 


\title{
Prolonging the Cut of Southern PINE
}

\author{
PAR'T I \\ POSSIBILITIES OF A SECOND CUT
}

By Herman H. Chapman

\section{INTRODUCTION}

Since 1907 the Yale Forest School has conducted the field work and instruction of the Senior class in the spring term in coöperation with lumber companies located in the southern states. The companies which have extended this coöperation are:

1907, Missouri Lumber and Mining Co., Grandin, Missouri.

1908, Kaul Lumber Co., Hollins, Alabama.

1909, Thompson Brothers Lumber Co., Doucette, Texas.

1910, Louisiana Central Lumber Co., Clarks, Louisiana.

1911, Thompson Brothers Lumber Co., Trinity, Texas.

1912, Crossett Lumber Co., Crossett, Arkansas.

1913, Southern Lumber Co., Warren, Arkansas.

In no case has there been a formal contract between the company and the School, but under verbal agreement the company has allowed the students the freedom of its mills and lands for purposes of instruction, built temporary wooden shacks for quarters in camp, instructed its employees to give such information as will be of assistance in instruction in logging and milling, and furnished commissary supplies at reasonable prices. The students maintain their own commissary in camp and pay all their own expenses.

The work is conducted primarily with the object of instruction, but a large amount of information is collected and given to the company. This consists of a topographic map, an estimate and description of timber and young growth, data on the growth of the timber, suggestions for management of the tract for the production of wood, and studies of present utilization and waste in logging. It has been possible so to combine training and practical work that although prepared by comparatively inexperienced students, the data and maps obtained have shown a creditable 
degree of accuracy and have in most instances proved of considerable value to the company.

The tract studied in the spring of 1912 at Crossett, Arkansas, is exceptionally well adapted to forest growth, and illustrates in a striking manner the possibility which presents itself to lumbermen throughout the South of modifying their methods of logging so as to get a second cut. During the six years of investigation in different southern states, the School has ascertained that probably over wide areas of longleaf and shortleaf pine the stand should be only partially removed in the first operation, leaving a fairly large percentage for a second cut in from fifteen to twenty years. If properly carried out this policy will secure a satisfactory rate of interest on the value of the timber left standing. This will be attained by rapid growth in volume and advance in stumpage values. Apparently it does not involve great expense at the present time.

\section{PRESENT POLICY IN THE SOUTH}

The present policy of most holders of stumpage in the South is clear cutting, which is followed by accidental or intentional broadcast burning of the slash, and sale of the land to settlers or land companies; and this is attempted in spite of the fact that there is at present no urgent demand for much of this pine land and that these timber companies still have ten to thirty years' cut in sight.

A few farsighted firms have attempted in places to limit the present cut to a certain diameter, reserving the small trees for a future crop. This is a move in the right direction, yet analysis shows that adherence to such a rigid diameter limit does not leave the most vigorous trees. It is not good business deliberately to leave an investment in the woods and secure only 3 per cent increase when, with the proper supervision, 6 or 7 per cent might be obtained on the same capital, yet that is just what is being done by most operators who are planning on a second cut. The others are neglecting an opportunity to prolong their business, lessen their annual depreciation charges, and secure future increase in stumpage values.

Clear cutting may be justified by the relative inaccessibility of the tract, making it unprofitable to return for a small second cut. Again, the land may be needed at once for agriculture, or the stumpage may be purchased without the land and require cutting clear. In most instances, however, this practice is due to lack of confidence in the methods demanded and absence of authori- 
tative information as to the growth and financial returns obtainable by leaving a stand for later removal.

While actual demonstration of results is the most convincing argument, it requires that some companies make the attempt, else the time will come when there will no longer be an incentive to existing firms to cut conservatively. A mill with twenty years' cut ahead is in better position to try out the plan than one with but five years to run. Even without such a demonstration it is possible to predict with fair accuracy the growth that will occur after cutting and to outline measures which will assure a second crop.

\section{REPORT ON LANDS IN ASHLEY COUNTY, ARKANSAS}

The report of the Class of 1912, Yale Forest School, to the Crossett Lumber Company, on their tract in Ashley County, Arkansas, is presented herewith. This report deals with local conditions. Previous work of the School in Louisiana and Texas indicates that similar conclusions may be drawn for the better and more accessible areas of longleaf and shortleaf pine throughout the South.

\section{MAPPING THE TRACT}

The area covered by this report includes approximately 27,000 acres lying south of Crossett, partly in Arkansas and partly in Louisiana. The greatest difference in elevation is about 150 feet and the country is either flat or gently rolling, with occasional abrupt slopes. Logging roads can be laid out with little regard to topography. This greatly lessens the value of a topographic map, but for purposes of instruction one was prepared on a scale of 2,000 feet to the inch, with horizontal contours showing 5 -foot differences in elevation. Upon this map streams, dry gulches and roads were shown.

The timber areas were plotted on the map in distinctive colors, according to character of stand. The stands shown are as follows:

(a) Mature pine timber chiefly of large size with insufficient young timber to justify a second cut.

(b) Pine timber of all ages containing enough young timber to justify a second cut.

(c) Brush land with hardwoods and scattered pine averaging less than 1,000 feet b.m. of pine per acre.

(d) Cut-over pine land with practically all mature pine removed. 
(e) Pine in old abandoned fields, usually a dense stand.

(f) Hardwood lands, usually bottomland with little pine.

In addition to the areas mentioned above, cleared lands under cultivation or in pasture are shown.

\section{ESTIMATE AND DESCRIPTION}

A timber estimate and full notes on the stand were made for the area covered by the map. The work was done by the students after eight days of training in timber estimating, and allowances nust be made for lack of experience and for variation in individual ability of the men. The method used was to count the trees in strips on half the area, correcting for differences in the stand where the timber stood unevenly on the remainder. One-third of the counted trees were measured by eye and tally kept of diameters and of the number of logs in each tree. The contents of these trees in board feet was derived from a table prepared from 300 felled trees on the tract. The stand on each "forty" was computed from this count and tally.

A percentage was deducted for loss from rot, and where there was damage from insects or windfall it was stated in percentage of the standing timber. The character of the merchantable timber was briefly described with reference to the size of the $\operatorname{logs}$, clear length and percentage of grades under "uppers," "No. 1 common," "No. 2 common," and lower grades, thus giving some idea of the relative value of the timber. The quantity and character of small or immature timber was noted, including its size and age and the area covered. The purpose of this description was to record the conditions on each "forty" so completely that no further examination would be necessary for any purpose.

\section{COMPOSITION OF THE FOREST}

The pine timber on this tract is composed of shortleaf and loblolly pine in almost equal mixture. This fact is unimportant from the market standpoint, because the two species are of practically equal value and not easily separated when manufactured into lumber. Loblolly grows almost pure on the lower flats and frequently forms pure stands on abandoned fields. It gradually gives place to shortleaf on drier soils and on the driest the shortleaf grows pure.

Pine forms almost pure stands on all the higher lands. It has the ability to resist droughts, which are frequent and severe during the growing season, the months of April, May and June. 
The droughts seriously interfere with the development of hardwoods on these soils and the only hardwood growth is a few very stunted and deformed oaks from which some timber is cut. Better hardwoods, including white and black oaks and some sweet gum and hickory, appear near streams where the soil is fairly well drained, moist and deep. The true hardwood stands occupy the bottoms, which are subject to overflow and where there is comparatively little pine reproduction. These lands were under water in the spring of 1912 during the unusual floods of that year and were not examined.

\section{DAMAGE}

The mature pine is fairly sound. Old stands show a large amount of red rot and a lesser amount of butt rot, although the cull seldom exceeds 10 per cent of the volume on any "forty" and averages less than 3 per cent.

Fire has done very little injury to the timber. A small percentage of the trees show scarred butts, often due to the burning out of faces chipped off to test the grain for shingle bolts. Most of the timber is sound at the base and escapes injury from ordinary surface fires.

The greatest loss to the timber results from wind. This is due to the soil, which in many sections is underlaid with hardpan from two to five feet below the surface, into which the tap root of the pine cannot penetrate. In consequence the tree is entirely dependent on the spreading lateral roots for its support. In very wet seasons, like the spring of 1912, the soil becomes quite soft. Often a heavy wind will uproot many trees. Some sections are more subject to wind damage than others and, through repeated losses, the forest there has assumed a clump-like, manyaged form. This condition is doubtless due to the presence of hardpan nearer to the surface than on the tracts showing less windfall. Tornadoes are very rare, although there have been one or two instances of very heavy loss over a limited area, necessitating immediate logging. More often scattered single trees, including young, small poles as well as older and larger timber, will go down here and there. Weak roots and resulting poor anchorage, rather than undue exposure to wind, seem to determine which trees blow over.

Insect damage is present on almost all sections examined. The bark-boring pine beetles (Dendroctonus sp.) are continually killing trees, both among the old timber and crowded young stands. Occasionally 5 per cent of the trees may be killed within three or four years. The insects first attack trees which are sickly or 
weakened and those tend to become centers of infection. If conditions are favorable, the insects may increase very rapidly and destroy the pine timber over wide areas. Under ordinary conditions their natural enemies, such as woodpeckers, keep the insects from doing excessive damage. Areas badly infested with beetles should be logged as soon as possible in order to lessen the danger of the beetles spreading to adjacent areas.

\section{AGE CLASSES}

The age of the pine timber in this vicinity rarely exceeds 150 years, although occasional very old trees may reach 200 years. Much of it is approximately even-aged, but seldom continuous over very large areas. It is more likely to be broken up into different age classes, clumps of large, overmature trees being interspersed among groups of young timber, small poles or seedlings.

On much of the pine land old timber occupies the soil to the exclusion of young growth. The spread of the roots of very large trees is much greater than that of their crowns, due in part to the great demand of old trees for moisture. Owing to this wide spread of the roots, old stands, even when fairly open, do not contain much young timber until the old trees begin to disappear from weakness due to rot, or destruction by insects, wind or lightning. The final form of such a stand is a few scattered old trees of large size in a forest of young timber of various sizes and ages.

\section{REPRODUCTION OF PINE}

Pine seedlings spring up readily everywhere, provided the seed reaches mineral soil. Surface fires are a great help in preparing a suitable seedbed. Seeds seldom, if ever, germinate on pine litter or hardwood leaves and not readily in grass. Abandoned fields that have been cultivated afford an excellent seedbed, but old pastures reforest very slowly. The conditions after logging, where the ground has been torn up by skidding, are excellent for pine reproduction. The only reason there are not more seedlings in the forest before logging is that they cannot live under the old timber. They often require more light than is available, but the most important factor is the soil moisture. The seedlings are killed in dry seasons by the old trees, which deprive them of moisture. Reproduction on cut-over lands is either destroyed by fire or prevented from starting through lack of seed trees. 
Old-field stands constitute an important part of the forest. Many of them are about forty-five years old and already large enough to cut. These stands are dense with sixty to eighty trees per acre, and the timber is frequently very limby because it has grown on open fields and with full crown development. This and the rapid growth of the timber reduce the quality and make it a poor logging proposition compared with the better grades and sizes of the older timber. These old-field stands will, in time, however, yield large crops of timber and of very good quality. A large percentage of the trees are, through crowding, already cleared of branches and from now on will, if thinned out, and the remaining trees given room to grow, add clear material at a rapid rate. At present many old-field stands are so densely stocked that the trees are making slower growth than they should.

\section{GROWTH OF PINE}

The rate of growth of both shortleaf and loblolly pine in this locality is rapid; it exceeds that found elsewhere the School has studied it.

\section{Table 1.-Average Growth in Diameter Breast High Outside Bark of Shortleaf and Loblolly Pine in Ashley County, Arkansas.}

(Basis 200 Trees)

\begin{tabular}{|c|c|}
\hline $\begin{array}{c}\text { Age, } \\
\text { Years. }\end{array}$ & $\begin{array}{c}\text { Diameter, } \\
\text { breast high. } \\
\text { Inches. }\end{array}$ \\
\hline 10 & 2.0 \\
20 & 4.7 \\
30 & 7.3 \\
40 & 9.5 \\
50 & 11.6 \\
60 & 13.6 \\
70 & 15.6 \\
80 & 17.5 \\
90 & 19.2 \\
100 & 20.6 \\
\hline
\end{tabular}

Table 1 gives the average diameter outside the bark at breast height ( $41 / 2$ feet) of trees of different ages from 10 to 100 years. It is based upon the measurement of 200 trees.

Since these species grow in mixture over most of the tract, it was thought best to obtain an average figure for both species rather than to determine the growth separately for each.

This rate of growth of about an inch every four years during the first forty years or an inch every five years for the entire 100 
years is for average trees, and shows that timber reaches merchantable dimensions from seed in from forty to fifty years. This is borne out by the growth of old-field stands. Six plots of five acres each measured in old-field stands showed yields of from 7,500 feet b.m. to 14,200 feet b.m. per acre, with ages from forty to forty-seven years. The more rapidly growing trees reach merchantable size in thirty years and old-field stands will yield 2,000 to 3,000 feet b.m. per acre when thirty-five years of age. In the next few years the yield of merchantable timber rapidly increases as the trees attain merchantable size.

Table 2.-Average Yield per Acre of Even-Aged Stands of Shortleaf Pine, Under Ordinary Conditions, on Large Areas in Ashley County, Arkansas.

(Doyle Rule)

\begin{tabular}{|c|c|c|}
\hline $\begin{array}{c}\text { Age of Stand, } \\
\text { Years. }\end{array}$ & $\begin{array}{c}\text { Yield per Acre, } \\
\text { Board Feet. }\end{array}$ & $\begin{array}{c}\text { Average } \\
\text { Growth per } \\
\text { Year, } \\
\text { Board Feet. }\end{array}$ \\
\hline 50 & 5,000 & 100 \\
60 & 6,600 & 110 \\
70 & 8,100 & 116 \\
80 & 9,600 & 120 \\
90 & 11,000 & 122 \\
100 & 12,400 & 124 \\
110 & 13,600 & 124 \\
120 & 14,800 & 123 \\
130 & 15,800 & 121 \\
140 & 16,600 & 118 \\
150 & 17,200 & 115 \\
\hline
\end{tabular}

Dense stands with a large number of trees per acre, such as occur on old fields, cannot maintain both numbers and rapid growth. The increasing demands of larger trees for soil moisture during the growing season cause the number of trees which can continue to thrive on an acre to diminish rapidly. When most of the trees are of nearly the same age and height, the crowding out of the weaker trees does not take place as rapidly as it should, and the growth of all the trees may be seriously retarded. In the ordinary forest the same crowding and loss of numbers occur, but the more broken and irregular character of the stand makes it less pronounced. Under average conditions yields of timber can be depended on to equal or exceed the results given in Table 2.

In fact, better yields per acre than this are obtained in the virgin forest on many "forties," and with any sort of management which secures good reproduction and affords protection, these yields should be increased by one-half, as is shown by the yields 
actually obtained on old-field stands. In other words, these are in no sense maximum yields, but may be obtained under almost any circumstances and without expensive measures.

These yields, shown in Table 2, may be increased from 50 to 100 per cent under proper management.

\section{MANAGEMENT OF THE TRACT}

The company desires to maintain as long as possible the present output. The estimate of merchantable timber indicates a cut of approximately eighteen years. The company believes that growth and the increase on old-field stands will extend the cut two years. The depreciation charge and investment in the plant have, therefore, only twenty years to run. If it can be shown that, by a different procedure, growth may be more fully utilized and the cut extended even two or three years, this policy would have much to recommend it from a financial standpoint.

\section{AGRICULTURAL POSSIBILITIES}

The land will not be kept permanently in forest by the present company and it is planned ultimately to dispose of it as farm lands. Old settlers do not consider the pine ridges suitable for continuous cropping and favor the lower lands, not overflowed, along small streams. These soils have better depth, more loamy texture and produce fair crops of corn, cotton or cane, while the pine ridges are likely to dry out and result in crop failures. With proper fertilization, improved methods of cultivation, better markets and the advent of truck crops, small fruits and orchards, much of this land will prove valuable for agricultural use.

The company is probably pursuing the proper policy in planning to dispose of the entire tract at some future time. But this by no means proves that it is unwise to encourage a crop of seedling pine on cut-over lands. In twenty years such seedlings will be five inches in diameter and with increasing scarcity of pine, and the small percentage of lands elsewhere that are coming up in young forest, this small timber will give the land a prospective value that may equal or exceed its value for agriculture and would aid greatly in its sale. By that time purchasers will be keenly alive to the value of young timber on land, even if desired for agriculture. Such portions of the farm as are not under cultivation should be in growing forest. 


\section{SECURING A SECOND CUT OF PINE}

The desire of the company to secure some return from growth has taken the form of instructions not to cut trees smaller than fourteen inches on the stump, equal to about twelve inches breast high. The carrying out of this rule is left entirely to the sawyers, under the rather hurried and indifferent inspection of the team boss. The method is an almost complete failure, for the following reasons :

(1) There is lack of proper inspection of the saw crews, who do practically as they please about taking or leaving trees.

(2) A diameter limit is wrong in application as it removes young, thrifty, rapidly growing trees if over fourteen inches and leaves standing tall, slender, poor-crowned old trees of very slow growth which ought to be cut.

(3) Trees are not selected for wind resistance and many trees so left will blow over because of weak roots.

(4) In stands of overmature timber often there are virtually no trees below fourteen inches in diameter that are suitable to leave.

(5) At present, trees left are not adequately protected from destruction by fires which consume the tops and débris after logging. They are apt to be a total loss from this cause.

(6) While leaving this nucleus for a second cut, no effort is made to protect smaller timber, which is often smashed in felling, slashed down for skids to support temporary spurs in wet weather, and burned by slash fires.

The sawyers are under instructions not to fell trees onto groups of small timber, but inspection is necessary to secure proper compliance with this or other rules.

\section{CONDITION OF THE CUT-OVER LANDS}

The condition of the cut-over land is at present very unsatisfactory. Only in widely scattered, occasional patches is enough young timber found to pay for a second operation. Elsewhere there has been practically no timber left standing and severe fires have burned the slash, destroying the immature pole timber. In places a dense crop of seedlings has sprung up, but over the greater portion of the cut-over lands fires and the lack of seed trees have prevented a new growth of pine, and only grass, worthless oaks and scrub sweet gum are coming in. 


\section{PROPOSED PLAN FOR SECURING A BETTER SECOND CUT}

The company should either abandon the plan of leaving trees below fourteen inches in diameter or it should adopt an entirely different policy involving the selection of the trees to leave and the proper handling of the fire risk. The latter policy appears best, provided it can be shown that it is comparatively simple to enforce and that it will result profitably. This involves the following essential points :

(1) Stands nct suitable for a second cut should be cut clear unless a few seed trees are left to restock the land.

(2) In stands which contain suitable young timber the trees to be removed should be marked and no others should be cut.

(3) Proper disposal of the tops must be secured under inspection to eliminate the fire risk and preserve the timber left standing.

\section{RESULTS OF EXPERIMENTAL MARKING FOR A SECOND CUT}

To present the subject concretely, certain areas were mapped and separated into (a) those upon which the timber was mature and not suitable for a second cut, and (b) those which were well adapted to a second cut because they contained young timber. The mature stands from which it will be difficult to secure a second cut were marked so as to leave for seeding purposes only healthy, rapidly growing trees as small as possible, which would stand until the next cut twenty years hence. This policy is not recommended except where the company decides that the securing of a complete stand of seedlings on the cut-over lands will justify the present expense.

On 200 acres so marked, the stand averaged 14,000 feet b.m. per acre, or 560,000 feet b.m. per "forty." By proper selection the seed trees selected contained 1,050 feet b.m. per acre or 42,000 feet b.m. per "forty," which is 7.5 per cent of the stand. The total number of trees per "forty" was 800 , or 20 per acre; this would be reduced by the proposed cut to 150 , or 3.75 trees per acre, which is 18 per cent of the whole number. It is evident from this that comparatively small trees were selected. The growth added to the seed trees will, because of their size, probably be between 2 and 3 per cent a year, or a possible 200 to 300 feet b.m. in ten years. In twenty years, the yield from these trees would probably be increased to 1,500 feet b.m. per acre. The 
actual sizes taken and left in each inch class on an average forty acres containing 810 trees are shown in Table 3.

Table 3.-Stand of Timber on an Average Forty Acres of Mature and Old Shortleaf and Loblolly Pine in Ashley County, Arkansas, Showing Total Number of Trees, Those to be Removed, and Those That Would Remain.

\begin{tabular}{|c|c|c|c|}
\hline $\begin{array}{l}\text { Diameter, } \\
\text { breast high, } \\
\text { inches. }\end{array}$ & $\begin{array}{l}\text { Total No. of } \\
\text { trees. }\end{array}$ & $\begin{array}{l}\text { Trees to be } \\
\text { removed. }\end{array}$ & $\begin{array}{l}\text { Trees to be } \\
\text { left standing. }\end{array}$ \\
\hline \multirow[t]{2}{*}{$\begin{array}{c}12 \\
13 \\
14 \\
15 \\
16 \\
17 \\
18 \\
19 \\
20 \\
21 \\
22 \\
23 \\
24 \\
25 \\
26 \\
27 \\
28 \\
29 \\
30 \\
31 \\
32 \\
33 \\
34 \\
35 \\
36 \\
37 \\
38 \\
39 \\
40 \\
41 \\
42 \\
\text { Over } \\
42\end{array}$} & $\begin{array}{c}50 \\
30 \\
30 \\
25 \\
37 \\
35 \\
42 \\
31 \\
47 \\
38 \\
52 \\
40 \\
55 \\
45 \\
43 \\
36 \\
38 \\
23 \\
26 \\
16 \\
17 \\
12 \\
13 \\
6 \\
8 \\
2 \\
4 \\
1 \\
4 \\
1 \\
1 \\
2\end{array}$ & $\begin{array}{c}26 \\
15 \\
16 \\
10 \\
21 \\
22 \\
29 \\
23 \\
38 \\
33 \\
47 \\
36 \\
51 \\
43 \\
42 \\
37 \\
36 \\
23 \\
26 \\
16 \\
17 \\
12 \\
13 \\
6 \\
8 \\
2 \\
4 \\
1 \\
4 \\
1 \\
1 \\
2\end{array}$ & $\begin{array}{r}24 \\
15 \\
14 \\
15 \\
16 \\
13 \\
13 \\
8 \\
9 \\
5 \\
5 \\
4 \\
4 \\
2 \\
1 \\
1 \\
1 \\
1 \\
= \\
= \\
= \\
= \\
= \\
= \\
= \\
= \\
-\end{array}$ \\
\hline & 810 & 658 & 152 \\
\hline
\end{tabular}

NUMBER OF TREES LEFT.

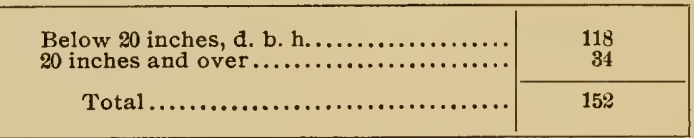

On areas adapted to a second cut, tabulation of actual marking on 200 acres shows the following results: average stand per acre, 8,129 feet b.m.; on forty acres, 347,292 feet b.m.; average stand per acre to be left after cutting, 1,805 feet b.m.; on forty acres, 79,300 feet b.m. Thus 22.2 per cent of the stand or 1,800 feet b.m. would be left as against 7.5 per cent or 1,050 feet b.m. in mature timber. The younger stands contained 1,051 trees 12 
inches and over, "breast high," on an average "forty," or 26.2 trees per acre. Stands composed wholly of young timber would have about 50 trees per acre. In the mixed stands, 457 trees would be left on a "forty" or 11.4 trees per acre, which is 43.5 per cent of the total number but only 22.2 per cent of the volume. How wide a departure from the rigid diameter limit the proper selection of trees makes is shown for an average "forty" in Table 4. In the method of individual selection it is seen that about one-third of the trees below 15 inches, one-half of those between 15 and 17 inches, and practically all 20 inches and over are to be removed. $\mathrm{A}$ few above 20 inches are to be left to provide seed for openings made by cutting large groups of old timber. They can be removed in the first cut if thought best.

Table 4.-Stand of Timber on an Average Forty Acres of Mixed Young and Mature Shortleaf and Loblolly Pine in Ashley County, Arkansas, Showing Total Number Trees to be Removed and Those That WuUld Remain.

\begin{tabular}{|c|c|c|c|}
\hline $\begin{array}{l}\text { Diameter, } \\
\text { breast high. }\end{array}$ & $\begin{array}{l}\text { Total No. of } \\
\text { trees. }\end{array}$ & $\begin{array}{l}\text { Trees to be } \\
\text { removed. }\end{array}$ & $\begin{array}{l}\text { Trees to be } \\
\text { left standing }\end{array}$ \\
\hline \multirow[t]{2}{*}{$\begin{array}{c}12 \\
13 \\
14 \\
15 \\
16 \\
17 \\
18 \\
19 \\
20 \\
21 \\
22 \\
23 \\
24 \\
25 \\
26 \\
27 \\
28 \\
29 \\
30 \\
31 \\
32 \\
33 \\
34 \\
35 \\
36 \\
37 \\
38 \\
39 \\
40 \\
\text { Over } 40\end{array}$} & $\begin{array}{r}163 \\
128 \\
119 \\
112 \\
99 \\
84 \\
66 \\
42 \\
38 \\
24 \\
21 \\
18 \\
20 \\
16 \\
15 \\
11 \\
12 \\
9 \\
8 \\
6 \\
5 \\
6 \\
6 \\
4 \\
4 \\
1 \\
2 \\
1 \\
5 \\
6\end{array}$ & $\begin{array}{l}67 \\
50 \\
48 \\
56 \\
48 \\
42 \\
37 \\
30 \\
29 \\
19 \\
18 \\
16 \\
18 \\
15 \\
15 \\
11 \\
12 \\
9 \\
8 \\
6 \\
5 \\
6 \\
6 \\
4 \\
1 \\
1 \\
2 \\
1 \\
5 \\
6\end{array}$ & $\begin{array}{r}96 \\
78 \\
i 1 \\
56 \\
51 \\
42 \\
29 \\
12 \\
9 \\
5 \\
3 \\
2 \\
2 \\
1 \\
= \\
= \\
= \\
= \\
= \\
= \\
= \\
= \\
= \\
= \\
= \\
= \\
=\end{array}$ \\
\hline & 1,051 & 594 & 457 \\
\hline
\end{tabular}

NUMBER OF TREES LEFT

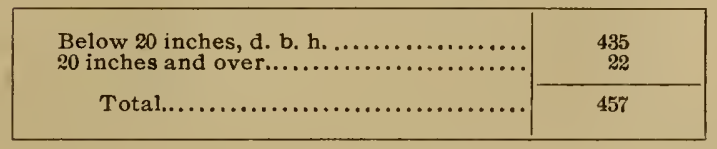




\section{NECESSITY OF MARKING TREES TO BE CU'T}

It is necessary to mark the trees to be cut instead of depending on an arbitrary diameter limit for the following reasons:

(1) Windfall. Opening a stand greatly increases the danger of windfall. Trees differ greatly in their wind resistance. Those growing in crowded clumps have weak roots, while thrifty trees growing in partial openings have well-developed roots. By selection of wind-firm trees to be left the danger of windfall in the remaining stand may be reduced to reasonable proportions.

(2) Growth. The purpose of leaving these trees is to secure growth which should be as rapid as possible. But trees differ remarkably in their rate of growth, a fact that can be verified by cutting into a few at random and counting annual rings of growth in the last inch of radius. The trees best to leave for the second crop are those making the largest growth per cent, based on the present volume of the tree. A small thrifty tree makes a higher growth per cent than a large tree because the volume of the former is less at present and the relative increase is much greater. The character of the crown indicates the vigor of the tree, since the growth is directly dependent on the amount of foliage, which, in turn, is determined by the available light and root space. Rapidly growing trees are sure to have thrifty, large and well-developed crowns. This can be told at a glance after a few days' practice.

(3) Soundness. All trees left should be free from rot, and sound at the base to lessen fire injury. Many trees below 14 inches in diameter are defective and unsuitable for leaving and should be removed.

(4) Welfare of the whole stand. Many stands of young timber are too crowded to make good growth during the next twenty years. Such stands should be thinned of about half of the trees, leaving, independent of diameter, those which show good crowns, a clear length and fast growth, and removing large, limby trees, and small, stunted, or slow-growing trees with poor crowns, and those that are defective or crooked.

\section{GROWTH IN THINNED STANDS}

If cutting is done on the basis of a rigid diameter limit, at least half the trees left will make poor growth. But if every tree left is properly selected the growth to be expected in ten years is indicated by measurements taken on 70 acres containing 8,837 feet b.m. per acre. The trees to be left after proper marking contained 2,630 feet b.m. per acre, or 30 per cent of the whole, 
which during the next ten years should amount to 4,466 feet b.m., which is an increase of 70 per cent in volume on the trees left standing.

This is explained as follows. The calculated growth of the trees now 12 inches and over in diameter will be 1,206 feet b.m. per acre, and the trees now below 12 inches in diameter which will grow to be over 12 inches in ten years will add 639 feet b.m. per acre, giving a total of 1,836 board feet. The stand to be left after cutting, viz., 2,630 feet b.m. per acre, is slightly better than the average, which will be nearer 1,800 feet b.m. per acre. The growth per cent, which includes the maturing of trees now. too small to cut, is conservative and might well exceed the above estimate of 70 per cent in ten years on all such stands. The reason for their rapid increase in volume is that the trees are in the best condition and of the best sizes for growth, while the removal of all slow-growing and large timber increases the relative average growth on those remaining.

\section{GROWTH IN VIRGIN STANDS}

The growth in virgin stands of pine in the next decade is determined by the age and condition of the timber. Stands from which the old, overmature trees have been removed present quite a different condition from that existing on the average "forty" of virgin timber. After trees have reached a certain size and age, they lose vitality, and succumb to heart-rot, insects or wind. The loss of one old tree, unless it can be logged, will offset ten years' growth on a great many others. Hence, if the stand contains a large proportion of old and large trees, it is probably not increasing in volume at all but the reverse, while the value of the standing timber may be sinking because of the progress of decay.

Owing to the tendency of these pines to grow in even-aged groups, and to the operation of natural destructive agencies, an even distribution of age classes from overmature to seedlings is seldom found on an area as small as forty acres. The timber will be largely overmature veterans, or young and thrifty, and the volume of the stand be actually decreasing, stagnant or increasing according to the age class which preponderates. On large areas it may happen that the annual decay and loss in virgin forests just equals the annual growth, while for any one stand this same balance will be attained in the course of time.

The tract of 70 acres selected for the study of growth after thinning and removal of mature timber contained a larger proportion of young thrifty trees than is found in typical overmature 
stands. A study of the probable growth on this same area indicated that if the stand were not cut, the growth in ten years would amount to 3,299 feet b.m., or 36 per cent of the present stand, making a total of 12,068 feet b.m. It thus appears that in stands similar to those selected, nearly twice the actual volume growth would be secured if the stand were not thinned than can be expected after thinning. Owing to the greatly reduced volume of the stand after thinning and the much greater average growth of the remaining trees, compared with those removed, the growth per cent, or ratio of growth to volume of stand on the thinned or cut-over tract, is double the per cent growth secured in the virgin stand. The stands selected represent those in good condition for growth, and not those containing a surplus of overmature timber. A reduction in the number of trees to 40 per cent of the former stand might be expected to reduce the growth in the next decade, and usually does so. Only in "forties" of overmature timber is there apt to be a net increase in growth after thinning, and this is due to elimination of loss from natural agencies. Even then, a fair stand of young timber must be present, as a basis for the second cut, to secure this result.

It is important, therefore, to emphasize the real advantage gained by leaving the smaller and thriftier trees for a second cut. This lies, as indicated, in the very large increase in growth per cent, obtained after thinning, upon the investment thus made. The leaving of virgin timber, even when thrifty, involves an investment measured by the volume, quality and stumpage value of the stand. Clear cutting terminates this investment. The growth in volume in virgin stands must be considered, not alone, but in its relation to the existing volume of the stand in which it is produced. While the growth in actual volume falls off as the result of removing four-fifths of the stand, the growth per cent of the remaining stand is twice what it was before the cutting.

\section{INCREASE IN VALUE OF SECOND CUT}

Seven per cent per year in volume does not represent the true increase in value of these thinned stands. The lumber produced from selected trees will be of high quality and value since they will be freer from knots and other defects. If stumpage values. advance, this increase will be still greater. It is safe to count on 10 per cent annual increase in value of properly marked stands containing the requisite quantity of young timber after cutting. These same stands would give scarcely 5 per cent increase in value per year before they are cut over, most of 
which would be due to increased stumpage values rather than growth.

\section{BRUSH DISPOSAL}

The mature trees are fairly safe from fire injury before logging, but the burning of the slash following logging will destroy practically all young timber. This menace can be avoided with slight additional expense. The remaining trees are able to endure any fire that is no hotter than the average surface fire that consumes six to eight years' accumulation of litter and needles. To avoid injury to the trees left after logging, it will be necessary (1) to keep the tops of the fallen timber about ten feet away from young standing trees; (2) to burn these tops when the flames will not be too hot, but will consume most of the needles and small twigs.

The first object may be accomplished at the time of logging by felling the trees away from small timber, and by lopping branches from tops which lie too close to young timber. It may occasionally be necessary to drag small tops away from young trees. The work can be done at slight expense by utilization of the present force under proper supervision.

Cutting and piling the tops cannot be justified for private operations in southern yellow pine. The burning must be done broadcast. Fire should be set in the slash as soon as possible after logging, but always when conditions are favorable. The rule should be to burn as soon as fire will take hold and never after the weather becomes dry and hot. To prevent hot fires in the slash wusis the summer months, all land should be burned over vefore logging and again as soon as possible afterwards, unless it seems feasible to keep fire out until rains occur. The problem of safe burning without injury to the remaining timber rests on intelligent supervision.

If the reserve timber is brought through this first burning, it can be successfully protected from subsequent fires, and it will be in condition to seed down the whole area and give rise to an abundant crop of seedlings. After the first six to eight years the set llings will be large enough to survive moderate surface fires.

\section{FINANCIAL ASPECTS}

Since the leaving of a portion of the stand which would otherwise be cut takes the form of an investment, the probable returns should be calculated. Assuming that 2,630 feet b.m. per acre left standing will increase in ten years to 4,466 feet b.m., this computation is easily made. 
With land valued at $\$ 5$ per acre and stumpage at $\$ 5$ per thousand, this investment should, after paying all expenses, yield 5 per cent compound interest at the end of ten years. Assuming an initial cost of marking of 10 cents per acre, and allowing 5 cents per 1,000 feet b.m. for lopping and burning the tops, an average stand of 8,000 feet b.m. gives an expense of 50 cents per acre. Tops can be piled and burned for from 25 to 50 cents per 1,000 feet b.m., and without piling, the expense is greatly reduced. The following is a summary of the initial investment:

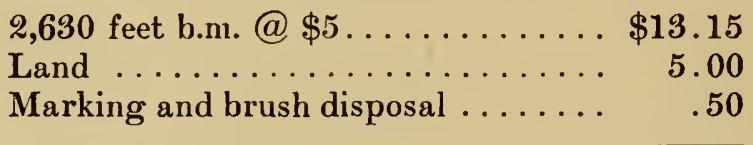

Total initial investment $\ldots \ldots \ldots \ldots \$ 18.65$ per acre.

Assuming there is a tax of 1 per cent on this valuation gives 18 cents per year. Fire protection if undertaken should not cost over 2 cents per acre, making a total of 20 cents per year for taxes and protection. Capitalizing at 5 per cent, this would mean an investment of $\$ 4$ per acre. This makes a total investment of $\$ 22.65$, which at 5 per cent compound interest amounts to $\$ 36.89$ in ten years. At that time if the land is still valued at $\$ 5$ and the $\$ 4$ capital used to supply the 20 cents annual charge is credited, the net cost of the timber in ten years at 5 per cent compound interest is $\$ 27.89$.

At this time the stand will contain 4,466 feet b.m. per acre. If it is worth $\$ 27.89$, it has paid 5 per cent, which is equivalent to a stumpage value of $\$ 6.25$ per thousand. It is fair to assume that this increase in price will occur in the ten-year period.

If the lands cut over are not left in a productive condition, they will lie idle until sold. No interest on the investment will be earned during this time, but taxes will continue and the total loss should be gauged by the compound interest on the money invested in non-productive lands. The price of land may rise, in which case the increased value will tend to off set this loss of interest. This would occur whether or not the land were cut over.

If the lands are not cut over, the original uneven-aged growth will probably increase in value, but at half or less than half the rate per cent on the investment that it would if culled of dead or unproductive capital. In either of the above cases, these lands as a whole, with growth balancing decay, are carried by the company at much greater relative cost than if put into condition for growth. 
Once the land is cut over properly, the investment in this second cut will carry itself independent of all other portions of the operation, and the investment left in the woods or spent for protection or taxes will, as a rule, be returned with 5 per cent compound interest when the final cutting is made.

Cutting should, therefore, be confined as much as possible to stands which are suitable for a second crop, since the sooner these are cut over the greater will be the amount of growth secured before the close of the whole operation. An exception to this rule is timber which is very old and decadent, which should be cut as soon as possible. But unless there is rapid deterioration, it will pay to hold mature timber for better prices.

\section{ADMINISTRATION}

The present superintendent of logging, the camp foremen and the team bosses are fully occupied with the details of the work as now conducted. Two extra employees are needed to assure proper enforcement of the provisions outlined to secure a second cut. One man could begin as saw boss and, while engaged at first chiefly in eliminating waste, direct or supervise the felling and secure the requisite amount of top lopping. Burning could be done by one or two laborers under his supervision.

The marking of the timber might easily be done by a second man who should cover a maximum of forty to fifty acres per day. Both of these men could be woodsmen or laborers of the better and more capable class. The saw boss would prevent more than enough waste to pay his salary, leaving the wages of the other man as a charge against the second crop. If, by his marking, the returns from growth can be increased from 1,000 to 1,800 feet b.m. per acre, which is a fair estimate of the improved growth resulting from the proper selection of trees, the net result of marking forty acres is an increased yield of 32,000 feet b.m. in ten years. At this rate the investment in wages for marking shows a good profit over the system of rigid diameter limits in cutting.

It is recommended that a forester familiar with southern pine be employed to train the woodsman in marking. The principles of marking are easily applied, but must be learned by actual demonstration before ordinary woodsmen can be trusted to carry them out successfully. The forester should classify the land on the basis of the second cut, make a type and timber map, and exercise supervision over brush disposal. He should study the cut-over lands, and the problem of windfalls and insect attacks, and be responsible for the efficient direction of all operations connected with prolonging the cut. 
Special attention must early be given to windfall, because damage from this source is most likely to occur within a year or two after the cutting.

\section{SUSTAINED PRODUCTION OF TIMBER}

It would be possible under proper management to maintain a perpetual supply of timber on the holdings of this company, but the present cut could not be sustained. Studies of possible yields on 9,000 acres showed that, under proper management and by cutting the large timber first, a cut of 150 feet b.m. per acre can be maintained for 100 years from the timber now on the ground. The mean annual yield on lands of average stocking is 125 feet b.m. (See Table 2.) Some land yields more than this, as, for instance, old fields, while much.land, because of poor stocking, is yielding less. A large per cent of the total forest area is now occupied by stands considerably more than 100 years old. The cut of 150 feet b.m. per year could be obtained, first, by a removal of the present surplus of old timber, and second, from actual growth. This figure was arrived at by computing the possible cut and probably growth on several tracts averaging about 2,000 acres each, on which the area of timber of each age class was known from field reconnaissance. This would include the cutting of all young timber and seedlings now growing, but would not include new crops of seedlings to be obtained in the future. One hundred years will allow the production of large timber with a high percentage of "uppers," probably 25 per cent. By cutting the present crops in seventy years a somewhat larger cut per year would be obtained for that period through a more rapid removal of the old timber, but the timber from then on would have to be cut when much smaller and less valuable if the cut is to continue.

With 150 feet b.m. per year, an annual cut of 15,000,000 feet b.m. could be obtained on a tract of 100,000 acres. Should such a policy be followed it would mean the saving of trees in mature stands to act as seed trees; the elimination of fire from cut-over lands for six to eight years after the slash had been burned; and it would stimulate the retention of lands in forests which would otherwise be sold for agricultural purposes.

The two most important questions, aside from the greater usefulness of the soil for agricultural purposes, are future transportation and logging costs, and future taxes. The logging operations on 100,000 acres managed for a second cut would be more scattered, with smaller cuts per acre and consequent increased costs. Taxes may increase greatly unless the education 
of the public on questions of public policy secures equitable tax laws, which will prevent unjust burdens of taxation on growing timber.

The forest itself is well adapted to continuous production. The unlogged portions present a complete series of age classes, which would enable the inauguration and perpetual maintenance of an annual cut. On the 9,000 acres studied there was of overmature or decadent timber, 1,890 acres, or 21 per cent; large sound, mature timber, 2,070 acres, or 23 per cent; small, merchantable timber, 12 inches and over in diameter, 1,710 acres, or 19 per cent; and of immature growing timber, poles and saplings, 2,880 acres, or 32 per cent; cleared farmland, 450 acres, or 5 per cent.

To a greater or less degree this proportion would hold good on most of the timberlands studied, although the percentage of overmature and large timber is greater in Louisiana.

Because of the large investment in mills and transportation, under present conditions, all that can be expected is a well-directed effort to obtain growth on the younger timber which is now large enough to cut or will become so inside of twenty years. At the end of that time, with all mature timber cut, it would be no longer possible to cut 150 feet b.m. per year and even if the reproduction of seedlings had been secured and the small pole timber left unharmed, the possible output from 100,000 acres would be very small for the succeeding thirty to forty years. If fires are permitted to run through the slash promiscuously and in the hottest weather, as is now the case, much of this cut-over land will be virtually devoid of any pine growth for a century, unless artificially restocked.

\section{SUMMARY OF RECOMMENDATIONS}

The measures necessary to secure a second cut are recommended as being inexpensive and practical.

The measures necessary to secure reproduction and protection of seedlings would involve a slightly increased expense, would promise no immediate financial return, but would preserve the productiveness of the soil by insuring a timber crop on land not farmed, and might prove ultimately of great financial value to the land owners when they come to sell these lands. These measures can be urged only as a matter of far-reaching public policy. If timber owners believe that a second growth of seedling pine will be of great benefit to the community and state, it is in their power to secure it on their own lands now at less expense than at any future time or 
by any other owner, yet such a policy might not be profitable to them.

Since it is possible that these lands may ultimately be used for agriculture, the state government can hardly be justified in any attempt to compel the timberland owners to undertake measures that will assure a permanent forest. States can encourage private efforts at reforestation by proper tax laws and fire protection, or such lands can be acquired by states and reforested at state expense. Along these lines, and not by arbitrary regulation, progress towards securing new crops of pine must be made. 


\title{
PART II
}

\section{CLOSE UTILIZATION OF TIMBER}

\author{
By Ralph C. Bryant
}

\section{INTRODUCTION}

The lack of close utilization of yellow pine timber is apparent on many operations in the South. In the following discussion some of the more common wastes are considered and a method suggested whereby lumbermen may prolong the life of their operations. The data were secured during the years 1907-12 in Missouri, Alabama, Louisiana, Texas and Arkansas. The need for the exercise of more care in felling and log making was distinctly shown in the discussion which followed the writer's presentation of this subject before the Southern Logging Association during its annual meeting in September, 1912.

\section{STUMPS}

Yellow pine operators in the past have cut high stumps and the loss of merchantable material from this source, in many cases, has totaled several per cent of the stand. The more progressive loggers now realize that this form of waste is needless and insist on stumps of a reasonable height, usually between eighteen and twenty-four inches. However, there are many instances where waste still occurs through lack of proper supervision of the saw crews.

There are several points to be considered in determining the proper height at which stumps should be cut. Among these are: (a) size of the timber; (b) soundness of the butt; (c) amount of pitch in the butt; and (d) labor conditions in the region.

In the case of sound trees stump heights should not be greater than the diameter of the trees at the cutting point, with a maximum height of 24 to 26 inches, even for the largest trees. That the latter heights are thoroughly practical for large trees is evidenced by the fact that careful operators use them.

Where butts are defective or pitchy there may not be any gain from cutting low stumps since the added material secured might be thrown away at the mill; however, the faller's judgment should not be taken in such cases without being checked by a saw boss. 
A difficulty is sometimes experienced by operators in securing low stumps when labor is scarce, because the lower the cut the more fatiguing the work, and unless all operators in a given section have the same standards, the workmen will seek employment with those who are most lax in their methods.

It may not always be possible to secure as much extra material by cutting low stumps and saving these sections as is shown in Table 5 , because of the possibility of having to leave a short section in the top of the tree which is not of sufficient length to make an added 2 feet on the top $\log$; nevertheless, the material saved in the butt log will be of greater value from the standpoint of both quality and quantity, because of the larger diameter and the freedom from knots.

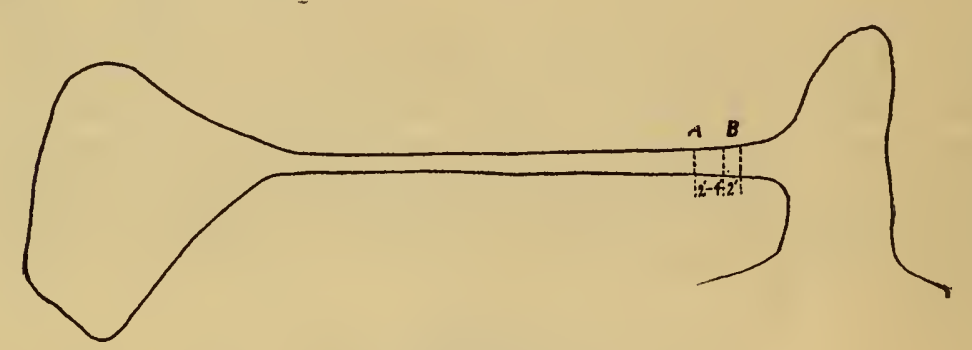

FIG. 1. METHOD OF CUTTING WINDFALLS.

A source of waste in stumps has frequently been observed on windfalls. The fallers, if left to their own judgment, will almost invariably make the first cut from 3 to 6 feet above the base of the tree, while in nearly every case it should not be more than 2 feet above it, as shown in Figure 1.

Table 5.-Amount of Timber in Stump Sections of Various Diameters and Lengths, Showing the Waste in High Stumps.

\begin{tabular}{|c|c|c|c|c|}
\hline $\begin{array}{c}\text { Diameter of } \\
\text { stump at } \\
\text { cutting point. }\end{array}$ & \multicolumn{4}{|c|}{ Excess heights on stumps. } \\
\cline { 2 - 4 } & 2 inches & 4 inches & 6 inches & 8 inches \\
\hline Inches. & \multicolumn{3}{|c|}{ Board feet, log scale (Doyle rule). } \\
16 & 1.0 & 2.0 & 3.0 & 4.0 \\
20 & 2.6 & 4.0 & 6.0 & 8.0 \\
24 & 3.0 & 6.6 & 10.0 & 13.0 \\
28 & 5.0 & 10.0 & 15.0 & 20.0 \\
32 & 7.0 & 14.0 & 21.0 & 28.0 \\
36 & 9.0 & 18.6 & 28.0 & 37.0 \\
40 & 12.0 & 24.0 & 36.0 & 48.0 \\
44 & 15.0 & 30.0 & 45.0 & 60.0 \\
48 & 18.0 & 37.0 & 55.0 & 73.0 \\
52 & 22.0 & 44.0 & 66.0 & 88.0 \\
\hline
\end{tabular}




\section{BREAKAGE OF BOLES IN FELLING}

The loss through breakage is largely due to the carelessness of the individual saw crews in felling trees on stumps and across down timber. A further loss usually occurs in cutting broken timber into logs, by making the saw-cut too far below the break. Where the break is not square across, it is often possible to obtain added material by cutting the log so as to include a portion of the broken end. This should always be done on large timber where the extra section that can be secured is at least equal to one-half the diameter of the log. (See Plate II, Fig. 1.)

\section{CROOKED TREES}

Crooked trees are common in yellow pine forests and greater care than is generally the rule should be given to cutting them into logs.

The tree should be divided into log lengths so that slight crooks will come on the ends of logs. If the sweep is pronounced, a section containing it should be cut from the tree and left in the forest.

Crooked logs are not only more difficult than straight ones to load and unload from cars, but they require several times longer to get them onto the carriage and to saw. As a result the output is often reduced from 20 to 75 per cent, thereby materially increasing the cost of the lumber to the manufacturer over that from straight logs.

The loss in sawing at the mill due to crookedness is greater on small than on large logs because a higher percentage of the small $\log$ is wasted in squaring.

\section{FORKED TREES}

Waste which usually accompanies the cutting of logs from forked trees is due largely to the following causes:

(1) Felling so that one fork of the tree is bedded in the ground, in which case the sawyers follow the line of least resistance and leave the log uncut. (Plate III, Fig. 1.) This can be avoided in most instances by felling the timber so that the forks will fall flat.

(2) Cutting too far below the crotch. This is well illustrated in the trees shown in Plate III, Fig. 1, where the cut could have been made seven feet nearer the crotch; in Plate III, Fig. 2, and 
Plate IV, Fig. 1, four feet nearer. The sawyers in each case disregarded their employer's interests and made the cut at the point where the least labor was involved. Although cutting at the proper point would, because of the swelling, have required more work, the value of the extra time consumed would have been only a small part of the worth of the timber saved.

(3) Cutting too far above the crotch. In the tree shown in Plate III, Fig. 1, the cut should have been made three feet lower on the tree and in Plate IV, Fig. 1, two feet lower, thereby saving 42 feet $\log$ scale in the first and 21 feet in the second case without additional expense for labor. The further waste of an 18-foot $\log$ fourteen inches in diameter (103 board feet log scale), shown in Plate III, Fig. 1, as partly bedded in the ground, can be explained as due to insufficient inspection. The stumpage value of the waste in this tree alone, at $\$ 4.50$ per thousand feet, is $\$ 1.60$.

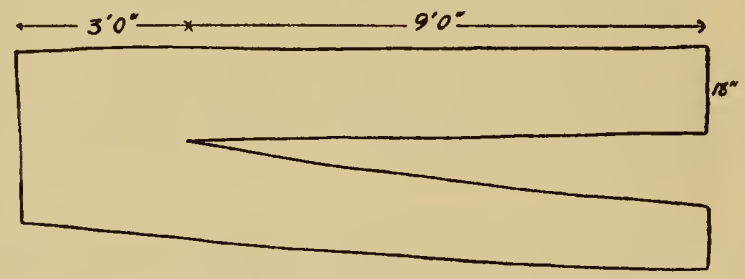

FIG 2. FORKED TREE IMPROPERLY CUT.

The waste of stumpage was not the only loss, since close observation of forked logs showed that in all cases the transportation and handling from the stump through the mill was accompanied by greater labor and expense than straight logs of the same diameter. An extreme case is illustrated in Fig. 2. The log was 12 feet long and 18 inches in diameter at one end, and because of its form was exceedingly difficult to handle. The yield of sawed lumber was not determined, but was estimated to be only 40 per cent of the full content of a straight 18-inch log. The following time was consumed in handling: from mill pond to mill deck, 12 minutes; throwing $\log$ out of $\log$ trough, 4 minutes; sawing, 13 minutes, a total of 29 minutes.

So much time was consumed in getting this log onto the mill deck that the band mill was out of logs for five minutes. The gang saw also ran out of cants and was idle for three minutes because of the stoppage of the band which was slabbing logs for it.

The thirteen minutes required for sawing was six times greater than the average for a straight 18-inch $\log 12$ feet, and the 
lumber yield was 60 per cent less, so that it would require fifteen times longer to cut a given amount of lumber from logs of this character than it would from sound straight ones. The loss in wages of the mill crew alone was greatly in excess of the value of the lumber secured from this particular log.

Although this is an extreme case, losses occur every time crooked or forked logs are handled. The cut of a single band mill may easily be reduced from 25 to 50 logs daily when many crooked and forked ones are handled, which means a reduction in output of from 3,000 to 6,000 board feet.
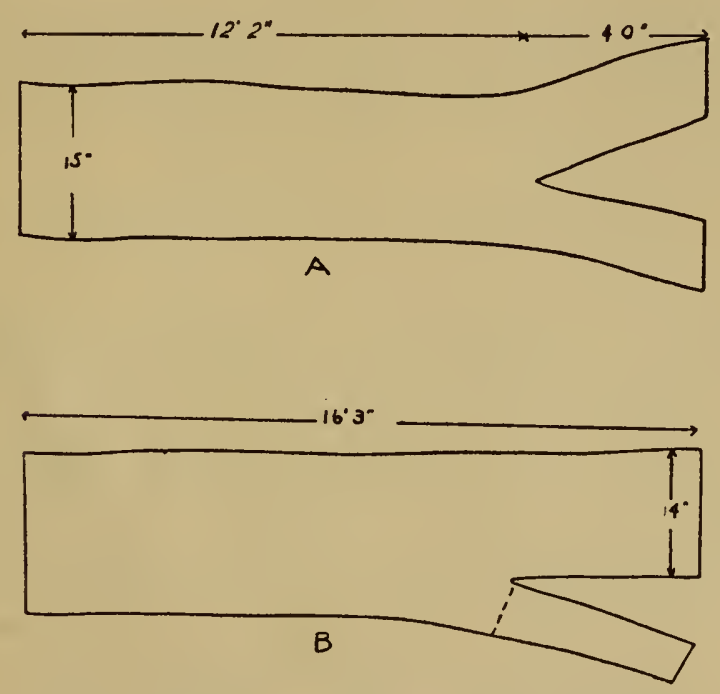

FIG 3. FORKED TREES IMPROPERLY PREPARED.

Further illustrations of logs actually observed on the skidways, in the woods, and on the decks of sawmills are given in Fig 3. These logs are not only difficult to handle, but in " $A$ " one end is worthless and should have been left in the woods. It would have been far easier to handle log " $B$ " had the lower fork been cut as shown by the dotted line.

\section{TRIMMING LENGTH OF LOGS}

Out of 1,000 logs measured on the skidways of a yellow pine operation, only 426 had the right trimming length, that is, from 3 to 4 inches. Of the remainder, 1411 logs had a trimming length of less than 2 inches; 100 logs, 2 inches; and 333 logs, 5 to 15 
inches. This variation was due either to carelessness in handling the marking stick or to the use of a stick of incorrect length. The ends of marking sticks are often accidentally cut off, and unless a new stick is at once secured, few of the measurements by the crew will be accurate.

The results of incorrect trimming lengths are readily apparent in watching the lumber pass over the trimmer in the mill. Boards that have a trimming length less than 2 inches are usually reduced 2 feet in length because the setter pulls the board past the fixed saw to secure a trimming edge and the far end usually falls short and is cut back to the next even 2 feet.

The total of the superfluous trimming lengths on the logs in a given tree when taken in connection with the merchantable material left in the top, is often sufficient to yield 2 or more feet of $\log$ length per tree over that actually secured.

\section{SELECTION OF LOG LENGTHS}

Every tree before being measured should be carefully examined and as far as possible the bole so divided that all high grade material is confined to certain logs and all low grade material to others.

Log-makers do not pay sufficient attention to cutting up boles on which punk knots and other indications of rot appear on the surface, often dividing them so that these defects come in the middle of logs instead of on the end. In the former case, if the rot has not extended more than a few feet in either direction from the defect, the log will have sound wood on both ends, which, however, is of little value because a high percentage of the board will be low grade or rotten. If the defect is on the end of the log, the unsound portion of the boards can be cut off in the mill and lumber of merchantable quality and length secured.

It should also be the rule in log-making to divide the bole so as to separate the knotty top sections from the clear portions, so that the latter can be worked up to the best advantage. A 12-foot $\log$ free from knots is of more value than a 16 -foot one that has numerous large knots, and there are instances where it is more profitable to leave the upper part of the tree in the woods if the logs thus secured yield a high percentage of the better grades.

Camp foremen frequently are not thoroughly familiar with the grades of lumber that logs with given classes of visible defects will produce, consequently their rules for the guidance of fallers in determining the extent to which unsound and knotty logs shall 
be utilized, are often very indefinite. As a result fallers cut trees that are too poor to be brought out at a profit, and on the other hand, leave logs that should be utilized.

\section{WASTE IN THE TOP}

A common form of waste is shown in Fig. 4. Fallers in measuring up the bole of the tree reach a point where there may be one to several large limbs on one side, as " $A$ " and " $B$," and they make their cut at "X," eliminating the rough portion of the bole. If the other side of the bole is free from limbs, as is often the case, the cutting point should have been extended 2 or 4 feet further, say to "Y," if that affords the proper log length. The object is to secure the added 2 or 4 feet of clear length on the lower half of the section, material that otherwise is wasted. If necessary, the large knots on the lumber secured from the upper half may be cut off on the trimmer. The clear half of the section will not lower the quality of the lumber secured, but, on the other hand, may slightly increase the percentage of the better grades and, in addition, the lumberman benefits by the greater amount of material secured. The added cost of handling the log in the woods and mill because of the extra 2 or 4 feet will be very small in comparison to the value secured.

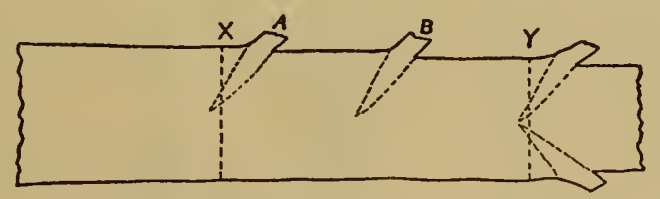

FIG. 4. METHOD OF CUTTING ROUGH TOPS.

Sections of merchantable timber partly or wholly free from knots, and from 1 to 12 feet long, are often left in the tops, due to inadequate supervision. (See Plate IV, Fig. 2, and Plate V, Fig. 1.) In order to determine the waste from this cause, a detailed study was made on $\mathbf{1 9 . 5}$ acres of logged lands belonging to a careful operator. This showed that 3.51 per cent of the total merchantable stand on the area had been left in the tops. The data were secured by measuring every felled tree on the area, great care being taken to scale only such part of each top as was considered merchantable by the owner. No length less than 2 feet was measured and the minimum diameter taken was 8 inches. In many cases where the length left in the top was in odd feet it would 
have been possible to have utilized completely the entire merchantable part of the bole had the log lengths been carefully marked off. The table gives a very conservative estimate of the waste in felling and log-making because it does not cover loss from high stumps, excessive trimming lengths, or of $\operatorname{logs}$ so cut that the best quality of material was not secured.

The yearly waste in tops on this operation, based on the annual cut for 1911, ${ }^{1}$ was $1,937,795$ feet b.m. (Doyle rule), and adding 25 per cent increase for overrun at the mill, it shows a loss of 2,422,243 feet b.m. Assuming stumpage is worth $\$ 4.50$ per 1,000 feet b.m., the annual loss is $\$ 8,770$. The profit secured from the sale of the sawn material, say $\$ 3$ per thousand feet, should be included with this, which brings the total to $\$ 14,533 .^{2}$

A gain of one year's cut (based on the cut of 1911) could be secured every 22.7 years, if the total merchantable timber on the lands were utilized. On the basis of a 20-year cut, the life of the operation would be prolonged 10.5 months.

Table 6.-Mrasurements on Cut-over Lands in Ashley County, Arkansas, Showing the Lack of Close Utilization.

(Doyle Rule)

\begin{tabular}{|c|c|c|c|c|}
\hline $\begin{array}{l}\text { Area in } \\
\text { acres. }\end{array}$ & $\begin{array}{l}\text { No. of trees } \\
\text { cut. }\end{array}$ & $\begin{array}{l}\text { Log scale } \\
\text { utilized. } \\
\text { bd. ft. }\end{array}$ & $\begin{array}{l}\text { Log scale } \\
\text { left in tops. } \\
\text { bd. ft. }\end{array}$ & $\begin{array}{l}\text { Total merch. } \\
\text { contents. } \\
\text { bd. ft. }\end{array}$ \\
\hline $\begin{array}{l}2.295 \\
1.147 \\
2.295 \\
2.295 \\
2.295 \\
2.295 \\
2.295 \\
2.295 \\
2.295\end{array}$ & $\begin{array}{l}38 \\
20 \\
59 \\
62 \\
52 \\
- \\
\overline{63} \\
41\end{array}$ & $\begin{array}{l}13,046 \\
12,455 \\
26,430 \\
28,660 \\
28,005 \\
20,778 \\
27,920 \\
38,350 \\
19,750\end{array}$ & $\begin{array}{r}1,025 \\
1,120 \\
1,206 \\
960 \\
68 \\
461 \\
648 \\
1,527 \\
816\end{array}$ & $\begin{array}{l}14,071 \\
13,575 \\
27,636 \\
29,640 \\
28,073 \\
21,239 \\
28,568 \\
39,877 \\
20,566\end{array}$ \\
\hline 19.507 & & 215,394 & 7,831 & 223,245 \\
\hline
\end{tabular}

Per cent of merchantable timber wasted in tops equals 3.51 .

The price of lumber 20 years hence will be far greater than it is to-day and the character of material that can be utilized will undergo a change; therefore, every year the operation can be extended will mean increased profits per thousand board feet of lumber manufactured.

Closer utilization will not mean an increase in the percentage of lower grades, but on the contrary the tendency should be the

1. The data was secured in 1912 .

1. The loss is in reality greater than this because the added expense of skidding, loading, hauling and sawing logs with an added $z$ or 4 feet length is only slightly in excess of the cost of handling the shorter logs, and the operator really secures this added timber at a very slight additional cost. 
reverse, because timber left in the tops is of as high grade as much of the material now taken; and the cutting of a tree for quality as well as quantity will increase the percentage of "uppers."

\section{SUGGESTIONS}

The successful solution of this problem can only be brought about by thorough inspection of felling and log-making. Where ten or more saw crews are employed, the proper supervision of this work will require the services of a saw boss, who should be responsible to the team boss in order that close coöperation may exist between felling and skidding crews.

A man to be a competent saw boss must understand thoroughly the mill requirements for logs, in order that the timber may be cut into the most desirable and profitable lengths; should be an expert log scaler; and must have the ability to teach and handle men successfully.

\section{DUTIES OF THE SAW BOSS}

(1) The distribution and care of all tools issued to fallers and log-makers. Economy is effected by a system of accounting for tools and other equipment. Special attention should be given to checking up the length of measuring sticks each day.

(2) Culling all trees and logs that are not worth handling.

(3) The instruction of the workmen in marking off log lengths on felled trees in order to enable them to secure the maximum quality and quantity of timber.

(4) The thorough inspection of the work of the felling and log-making crews to point out mistakes for the purpose of avoiding them in the future.

(5) The scaling of all timber that is felled.

Difficulties will be experienced at the start, but instruction by a saw boss for three or four weeks will result in a marked improvement in the work. Careful supervision, however, will be required constantly, for it is easy for workmen to fall back into old habits.

The saw boss should, after a few weeks, have sufficient time to scale the timber at the stump, since his inspection duties will require him to visit every felled tree. The wages of a scaler can thereby be saved.

The salary of a competent saw boss should be at least $\$ 100$ per month, because a man without proper conception of the work would be of little value. 
The successful inauguration of a scheme of this sort should involve some reward for the laborer who does his work well, inasmuch as he is called upon to exercise greater care and intelligence, and the additional profits accruing to the lumber company should, in part, be shared with him. This reward might assume the form of a bonus of a few cents per thousand feet of timber cut, or a slight increase in the daily wage. 


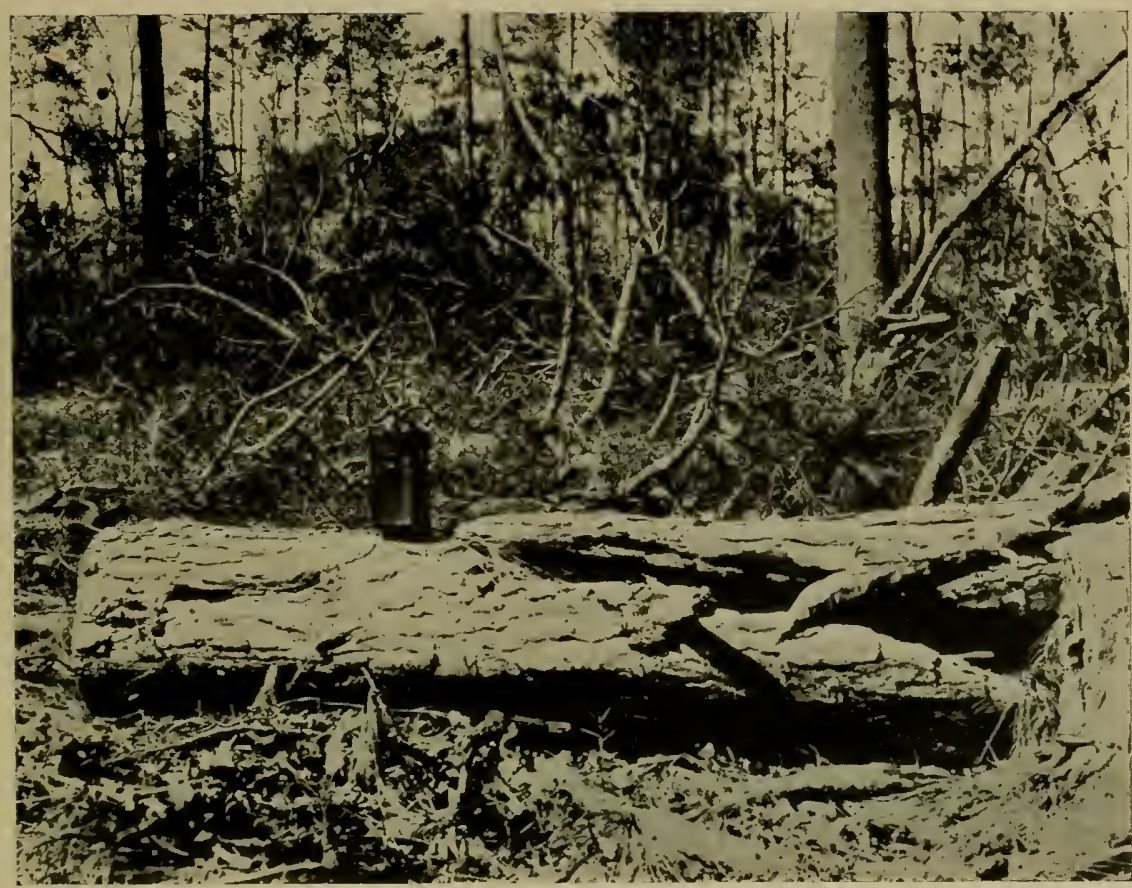

FIG. 1-TOP BROKEN FROM FALLING ON A STUMP

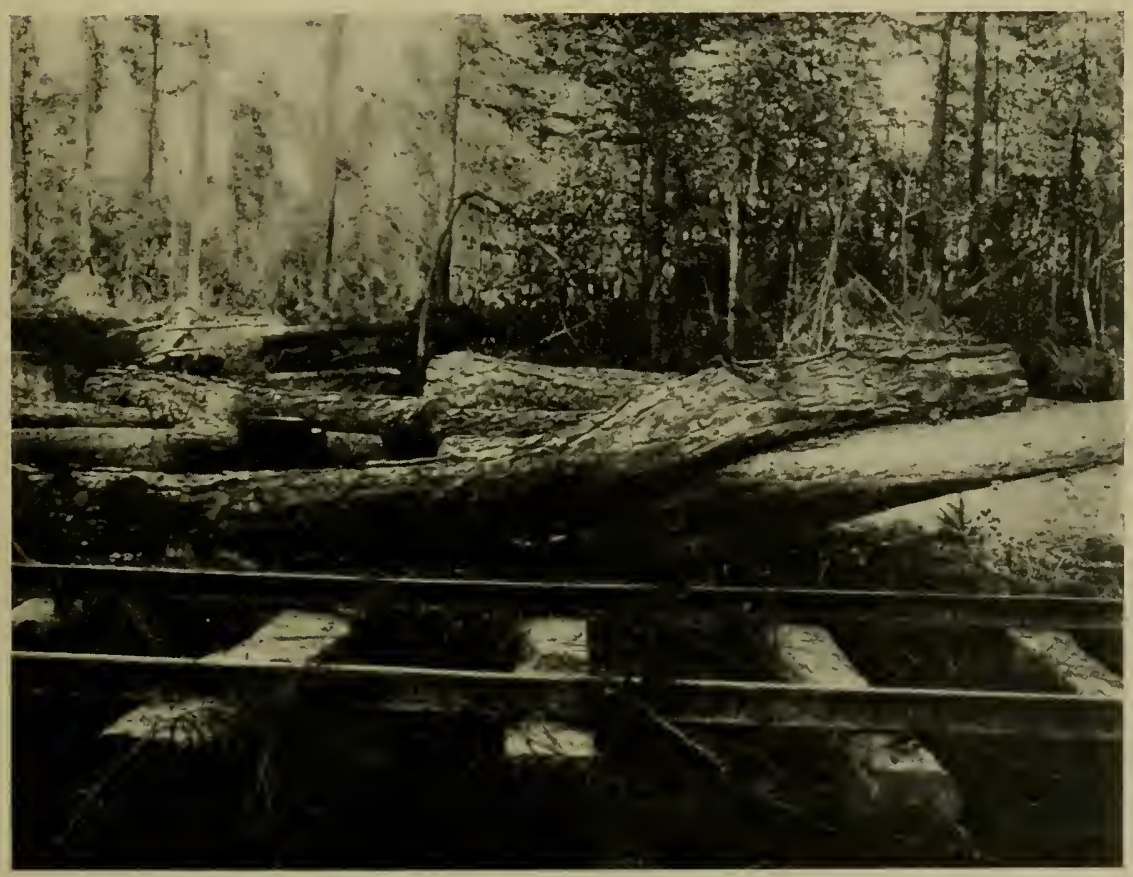





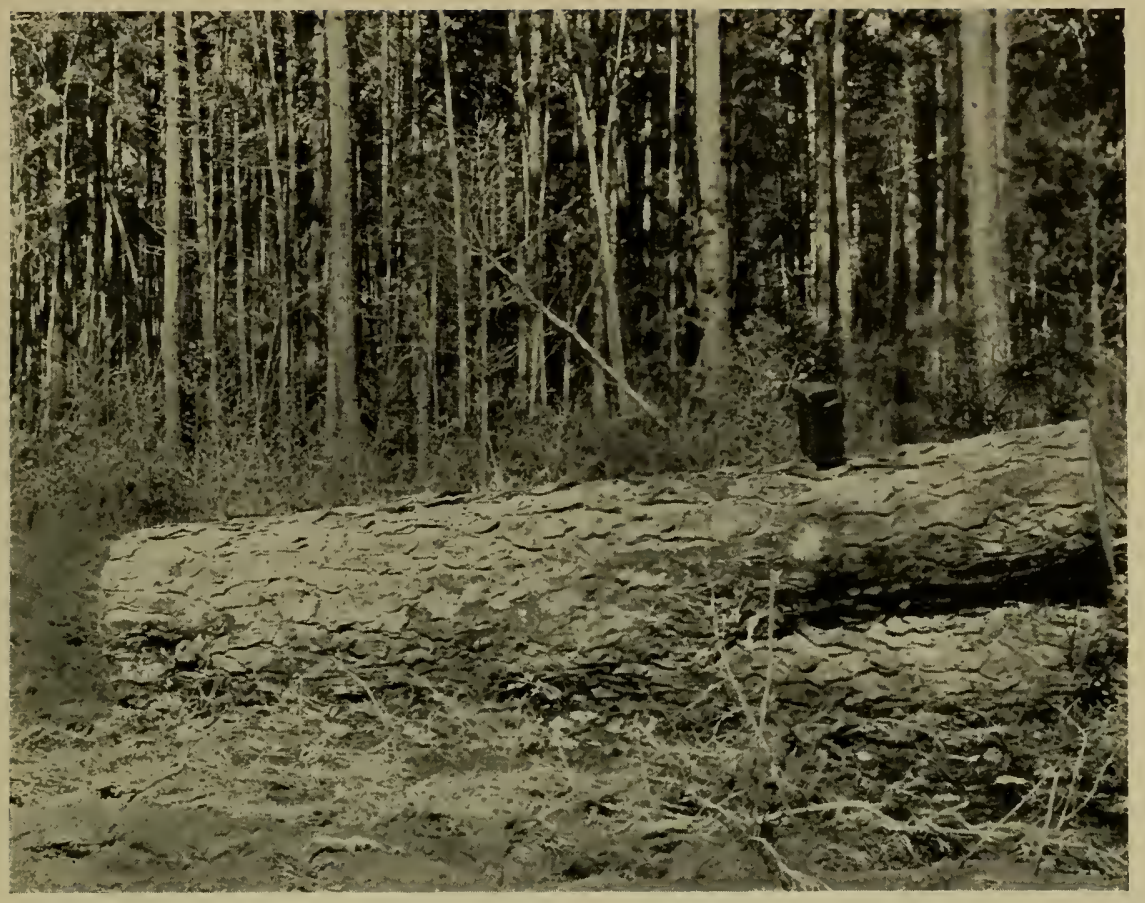

FIG. 1-EXAMPLE OF VERY WASTEFUL CUTTING OF A FORKED TREE

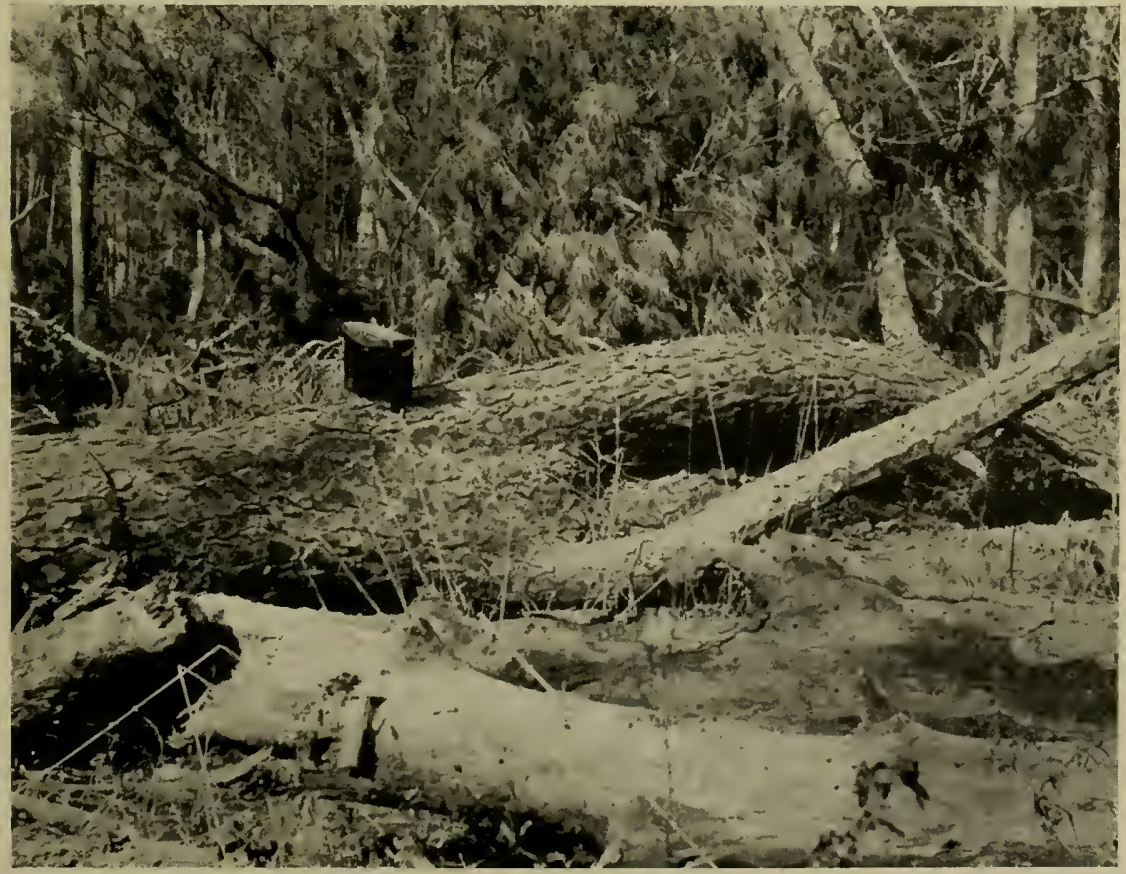

FIG. 2-UNNECESSARY WASTE IN LOG MAKING 



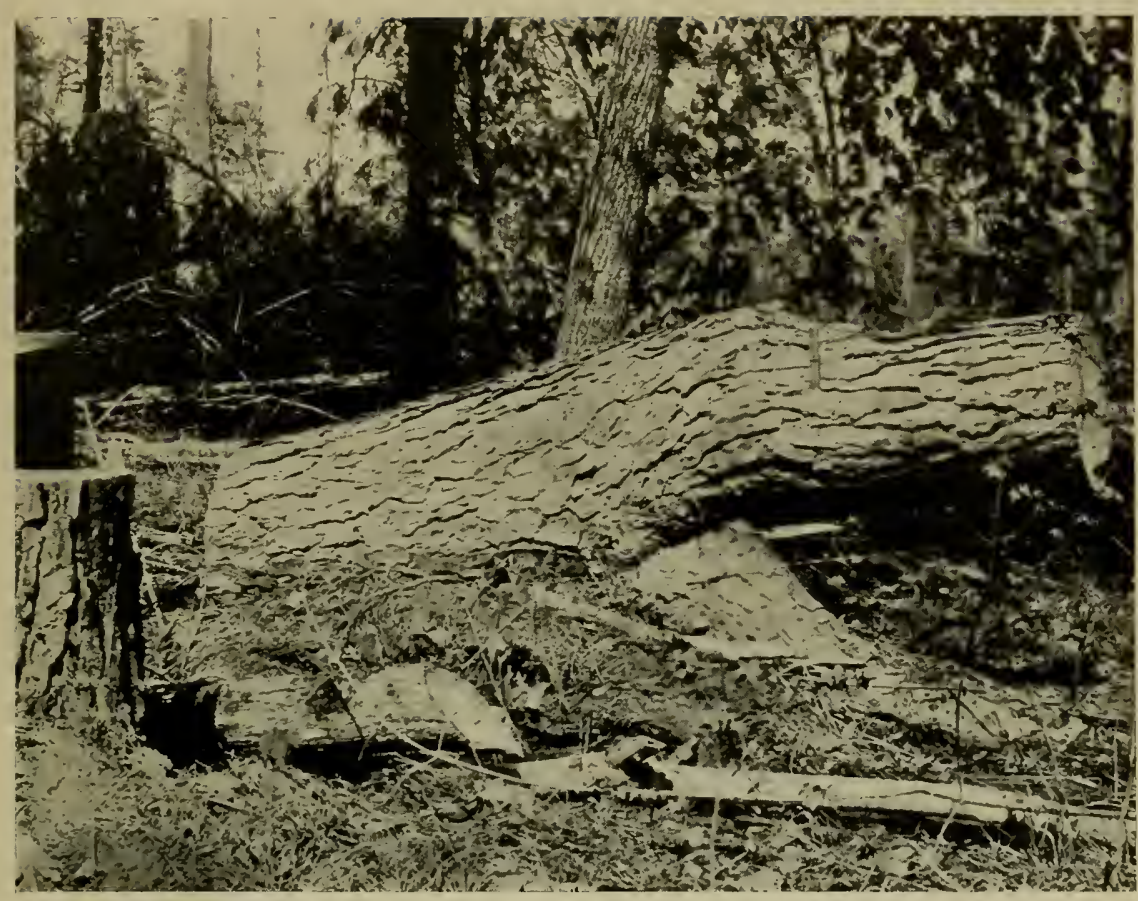

FIG. 1-SECTION BELOW THE TOP SHOWN IN PLATE V

(1) A 1. F

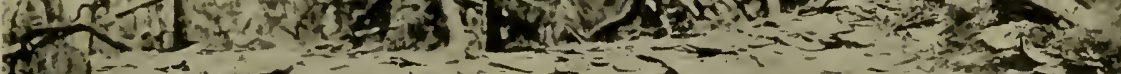

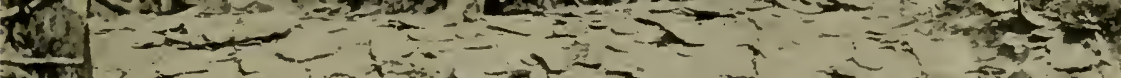

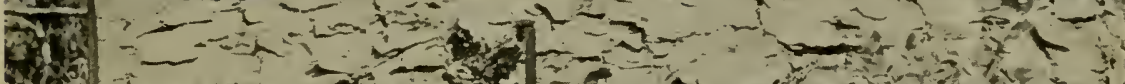
196 (1)

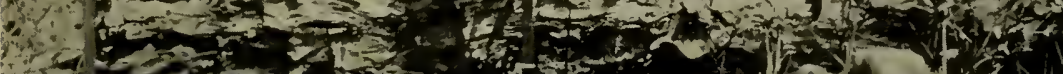

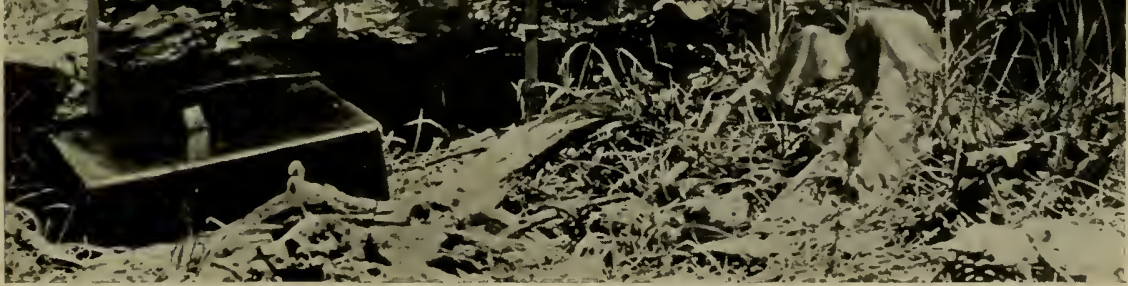




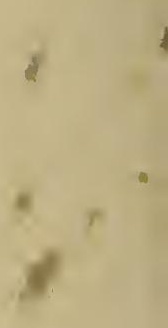


\section{and

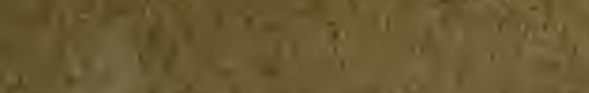

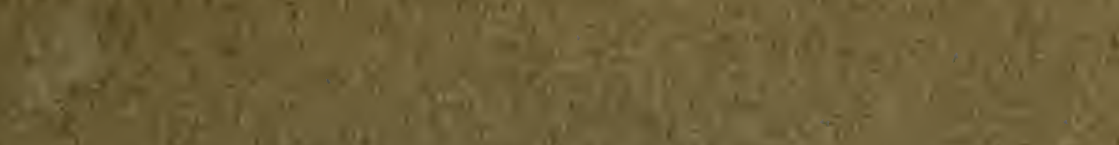
W. 20.7. a

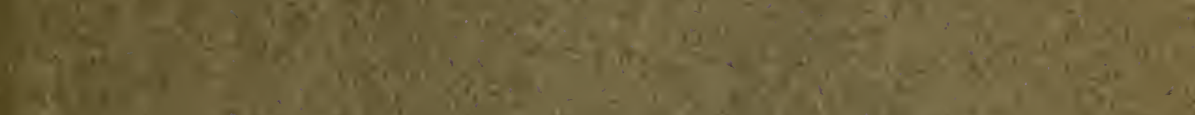

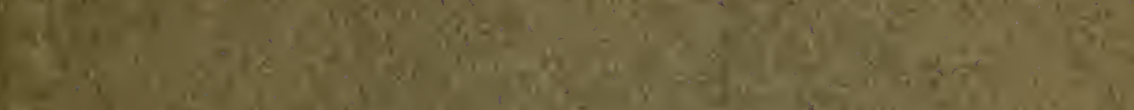

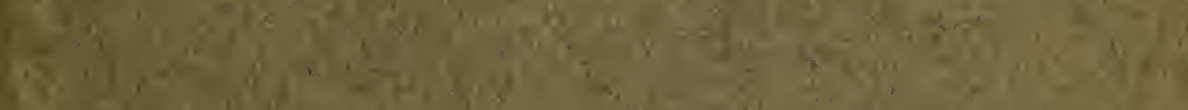
E.t.

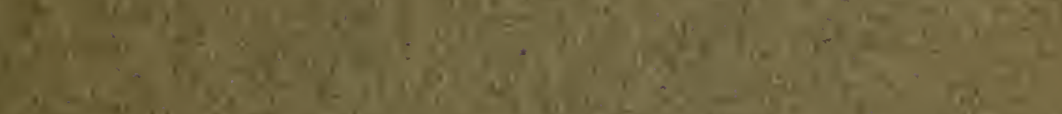

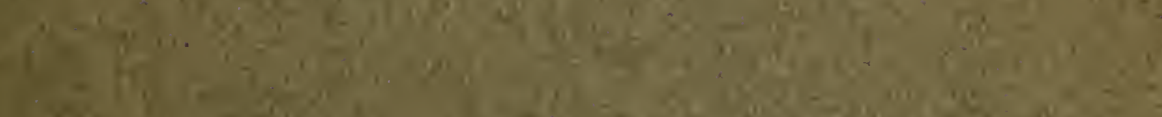

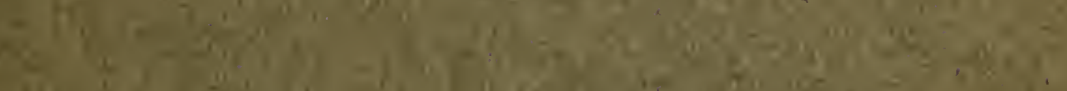

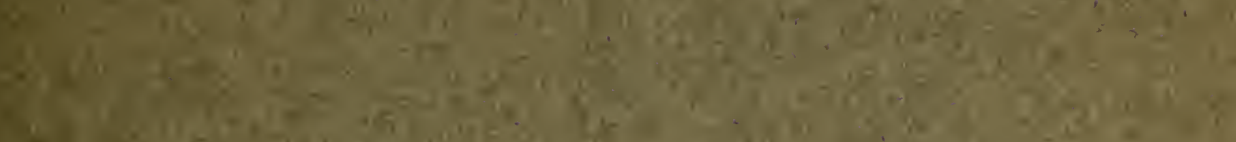

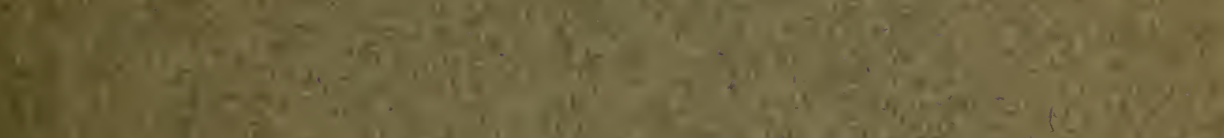

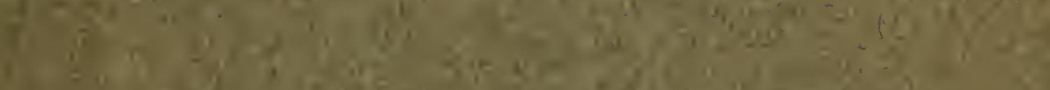

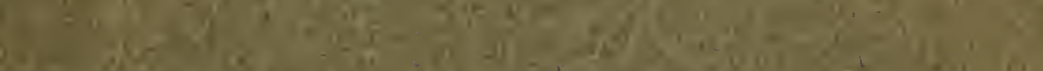

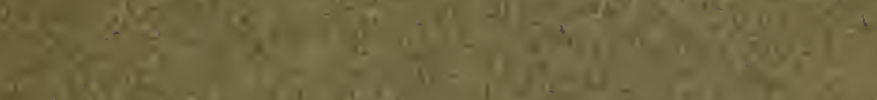

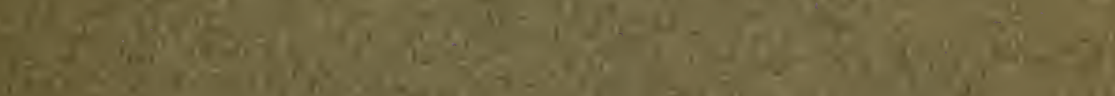

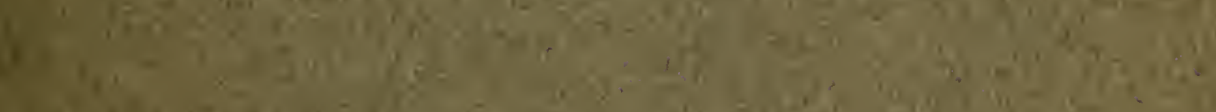

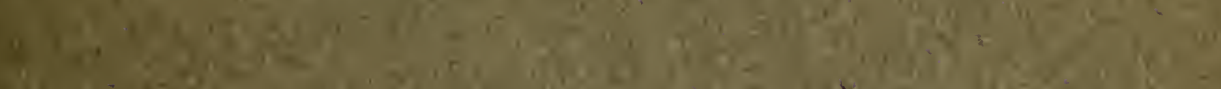

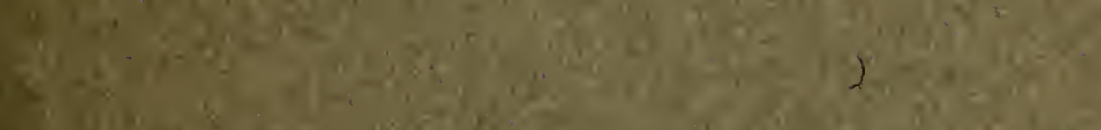

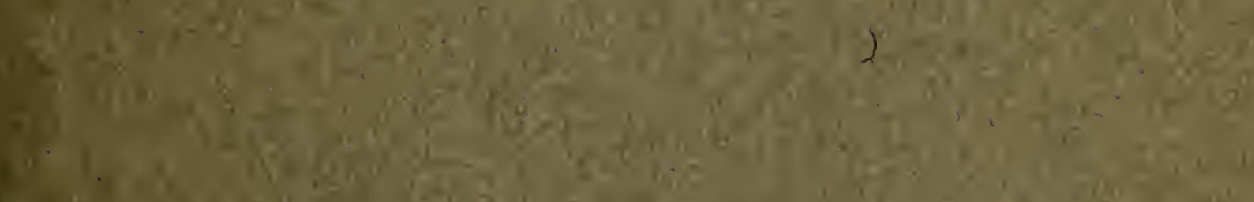

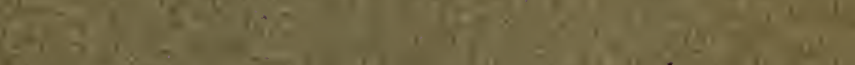

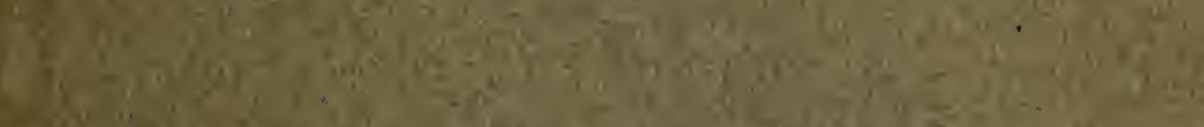

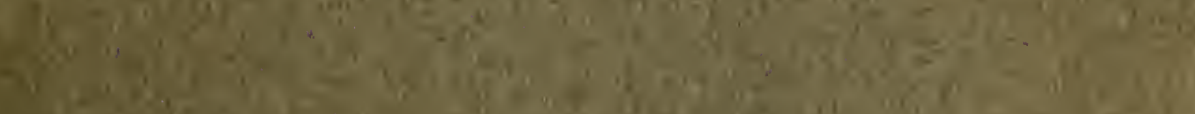

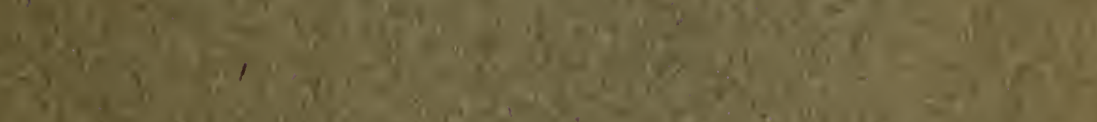

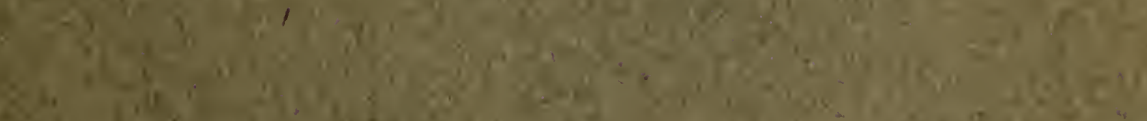

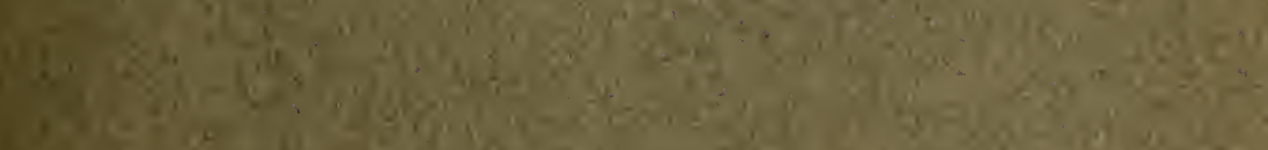

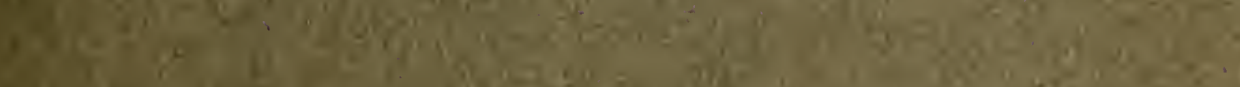

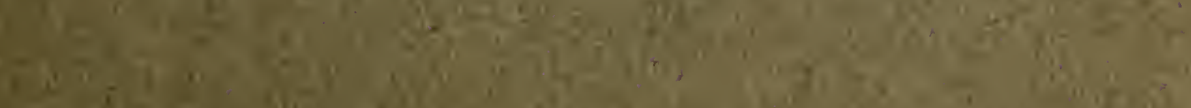

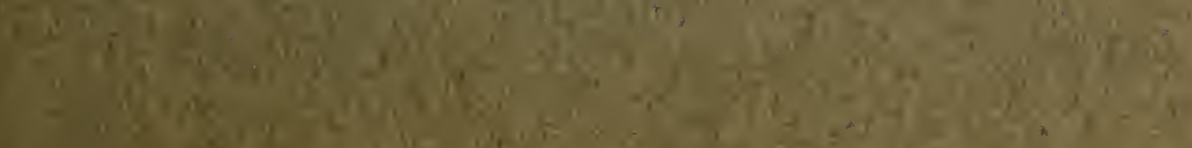

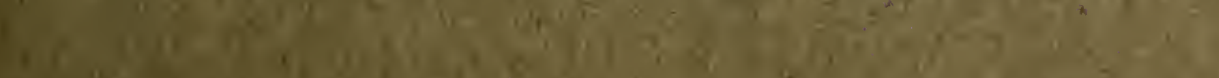





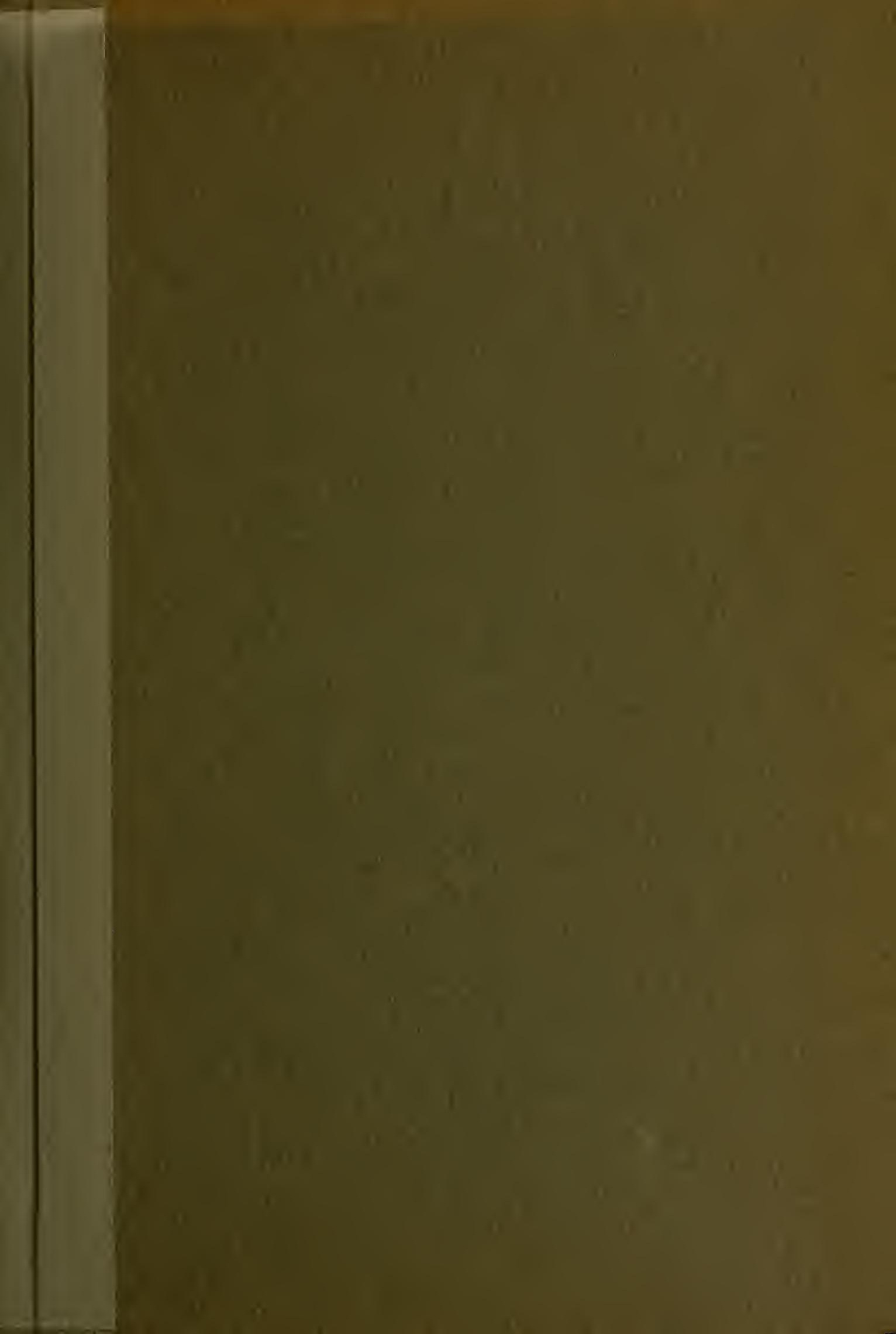


LIBRARY OF CONGRESS

|

... (n. (n) (n)

00008850276 